\title{
GROWTH OF HAWAIIAN CORALS
}

\author{
BY \\ CHARLES HOWARD EDMONDSON
}

BerNice P. Bishop Museum

BULLETIN 58

HONOLUL, HAWAI

Published by the Museum

1929 


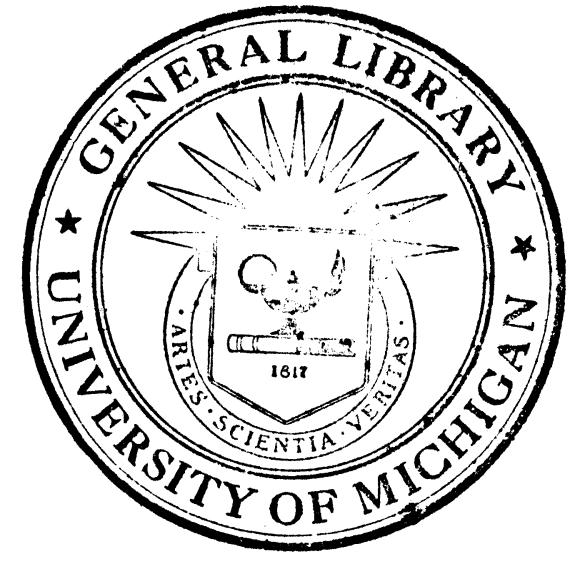


• 


\title{
GROWTH OF HAWAIIAN CORALS
}

\author{
BY \\ CHARLES HOWARD EDMONDSON
}

BERNICE P. BISHOP MUSEUM

BULLETIN 58

HoNOLUL, HAWAII

Published by the Museum

1929 
$A M$

101

.054

20.58 


\section{CONTENTS}

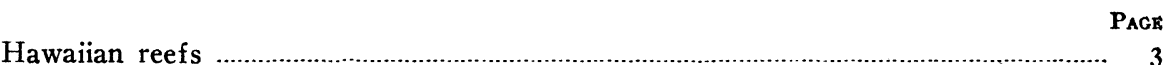

Morphology and behavior of planulae ............................................................................. $\quad 5$

Previous records of coral growth................................................................................ $\quad 18$

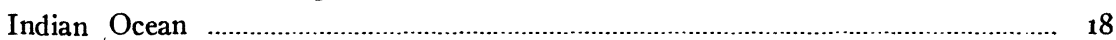

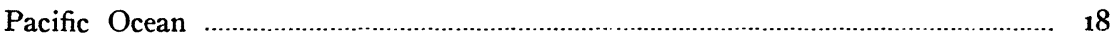

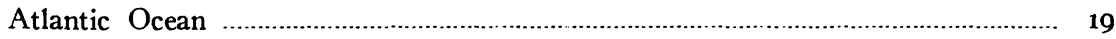

Methods of work

Growth-rate of Hawaiian corals.................................................................................. $\quad 20$

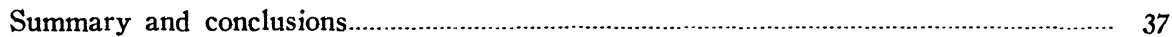

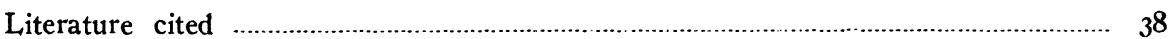

\section{ILLUSTRATIONS}

PuAre I. Species of Hawaiian corals... Page

PLATE I. Species of Hawaiian corals..................................................................... 39

II. Species of Hawaiian corals................................................................... 39

III. Species of Hawaiian corals ........................................................................ 39

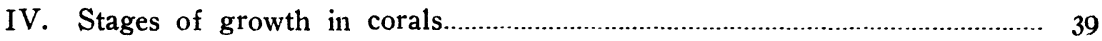

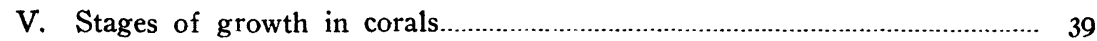

Figure 1. Planulae of Dendrophyllia manni and Pocillopora cespitosa......................... 6

2. Polyp of Pocillopora cespitosa; planulae and polyp of Cyphastrea ocellina 9

3. Skeleton of Cyphastrea ocellina; polyps of Dendrophyllia manni and Pocillopora cespitosa ................................................................ 13

4. Sections of planulae of Cyphastrea ocellina ..................................................... 16 


\title{
Growth of Hawaiian Corals
}

\author{
By Charles Howard Edmondson
}

\section{HAWAIIAN REEFS}

Shallow-water species of corals border most of the Hawaiian islands from Hawaii on the southeast, with very restricted reefs, to Ocean Island about 1800 miles to the northwest. No reefs have become established about Kaula, Nihoa, Necker, and Gardiner islands, which rise abruptly from deep water.

The reefs of Oahu, which may be considered typical of the Hawaiian group, when compared with representative ones of Fiji or Samoa in the South Pacific Ocean, or Palmyra or Wake islands in the North Pacific Ocean, are obviously inferior both in extent and vigor of growth of their coral population. Species of Acropora, so conspicuous on the reefs of islands of the South Pacific Ocean and also of Wake Island, are absent from Hawaiian waters, as are also the hydrocorallines. Forms of Pocillopora and Porites, which make the best showing on the reefs of Oahu, are here not so numerous in individuals or so vigorous in growth as closely related species in many other localities of the Pacific Ocean.

Vaughan $(14)^{1}$ records 14 genera comprising 77 species and divisions of corals in Hawaiian waters down to 25 fathoms, and I have studied 23 species, varieties, and forms taken in less than 1 fathom of water on Waikiki reef. Probably more than 30 species and varieties could be obtained on a typical Hawaiian reef without the aid of a dredge.

In a previous paper (7) I pointed out that coral colonies were more stunted on the south or leeward side of Oahu than the same species in Kaneohe Bay and other localities on the windward shore. A specimen of Pocillopora ligulata from windward Oahu measured $28 \mathrm{~cm}$. high and $35 \mathrm{~cm}$. broad, which is larger than any colony of the species $I$ have seen on the leeward reefs. A colony of Pocillopora meandrina var. nobilis on Waikiki reef attained a height of $21 \mathrm{~cm}$. and a breadth of $36 \mathrm{~cm}$. Even larger colonies of this species are common in Kaneohe and Kahana bays, windward Oahu.

It is obvious, however, that colonies of Pocillopora do not grow indefinitely. They probably have an age limit of 10 to 15 years. Vaughan (15)

\footnotetext{
${ }^{1}$ Figures in parentheses refer to the Literature Cited, page 38 .
} 
and Guppy (9) have shown that some corals cease to grow and soon die after reaching a certain size. The large colonies of Pocillopora on Hawaiian reefs represent hardy specimens that have had exceptionally long lives.

The largest colonies on the Hawaiian reefs are species of Poritcs. Specimens of Porites evermanni and forms of Porites lobata between 1 and 2 meters in height or breadth may occasionally be found on the reef platforms about Oahu. The largest colony of Porites cvermanni which I measured on Waikiki reef was $\mathbf{1 . 2}$ meters in diameter, being low and flat. Some of the larger colonies of this genus in Hawaii are probably from 100 to 200 years old.

Mayor (12) reports some colonies of Porites on the Great Barrier Reef to be 20 feet in diameter, but did not observe any in Samoa over 9.6 feet across. About Palmyra Island, thickly dotting the shallows outside the lagoon and in the channels between the islets, are massive coral heads, many of which are more than 2 meters in height or breadth. Wake Island is apparently completely surrounded by a reef of almost pure coral of considerable thickness. Huge blocks from 3 to 5 meters across, torn from the edge of the reef and thrown upon the land by typhoons, show coral calicles extending entirely through them, indicating a continuous growth for a very long period.

Additions to the volume of a reef may be represented by the united action of constructive agents minus destructive ones. Calcareous algae, corals, and other lime-secreting organisms are important contributors, together with material precipitated from the sea water and that washed from the land. Increases thus made may be counterbalanced by a constant wearing away process. Mayor (12) estimated the destructive action to equal the constructive one on the Samoan reefs.

From the decadent appearance of the reef platforms about the Hawaiian islands, covered by a fathom or less of water at low tide, it is probable that gains here are exceeded by losses. However, all along the outer edges of the reef platforms, at depths of from 2 to 4 fathoms, the growth of corals is much more prolific. Especially about windward Oahu, in Kaneohe, Kahana, Kawela, and Waialua bays, species of Pocillopora, Porites, and Montipora are well developed at such depths. Remarkable expanses of incrusting species of Montipora, 1 meter or more across, occupy much of the rim of the reef in Waialua Bay, far exceeding in number and size colonies of the species in near-shore areas. High temperature, silt, dilution of sea water, and seaweeds are ecological factors deleterious to corals in the shallow water of a reef platform. Colonies of species advancing shore- 
ward in Hawaii have constantly met with opposition from many sources, limiting both development and distribution. Although the surface of a typical Hawaiian reef platform is, for the most part, comparatively inert, considerable activity of calcareous algae as well as corals is seen on the outer rim beyond the range of many retarding influences.

It is probable that but slight upward growth of Hawaiian reefs has occurred in recent times, and the evidence seems to show that the coral population, when the elevated reefs were submerged, was about the same as now. Raised reefs of Oahu and excavations, such as the Waikiki drainage canal, indicate the presence of the same species of corals and about the same density of population when the elevated sections were under water as are now seen on adjacent submerged portions.

\section{MORPHOLOGY AND BEHAVIOR OF PLANULAE}

Three species of Hawaiian corals, Dendrophyllia manni, Pocillopora cespitosa, and Cyphastrea ocellina, have supplied material for a study of their planulae and postlarval development.

Colonies of Dendrophyllia manni (Pl. III, $D$ ) are, on the reefs of Oahu, best developed in Kaneohe Bay, on the windward side of the island. From here specimens were transported to the Marine Biological Laboratory at Waikiki for experimental work.

I have observed planulae of this species to be released by different colonies in August and October. For nearly a week, early in October, planulae swarmed from all colonies under laboratory conditions. They were expelled singly or in dense streams, periods of activity and quiescence alternating at irregular intervals during day and night. The temperature of the water ranged from $26^{\circ} \mathrm{C}$. to $27^{\circ} \mathrm{C}$. during the day, falling about $2^{\circ} \mathrm{C}$. at night. Other colonies, during another year, gave off small numbers of planulae for a few days about the middle of August. The maximum temperature during this time reached $27.3^{\circ} \mathrm{C}$.

Following the remarkable swarming of planulae in October, at no time during 12 months of observation were others released from these laboratory specimens. Attempts to expel planulae from colonies that had given off large numbers were made at other times of the year by modifying temperature, salinity, and other ecological conditions, but without success.

When first released the planula of Dendrophyllia manni is elongate-oval in form and about $2 \mathrm{~mm}$. in length. (See fig. 1, a.) As the organism moves through the water, propelled by fine cilia that completely cover the surface, the broader, aboral end is in advance. Like the adult polyp, the planula is brightly colored, ranging from orange to brick-red. 

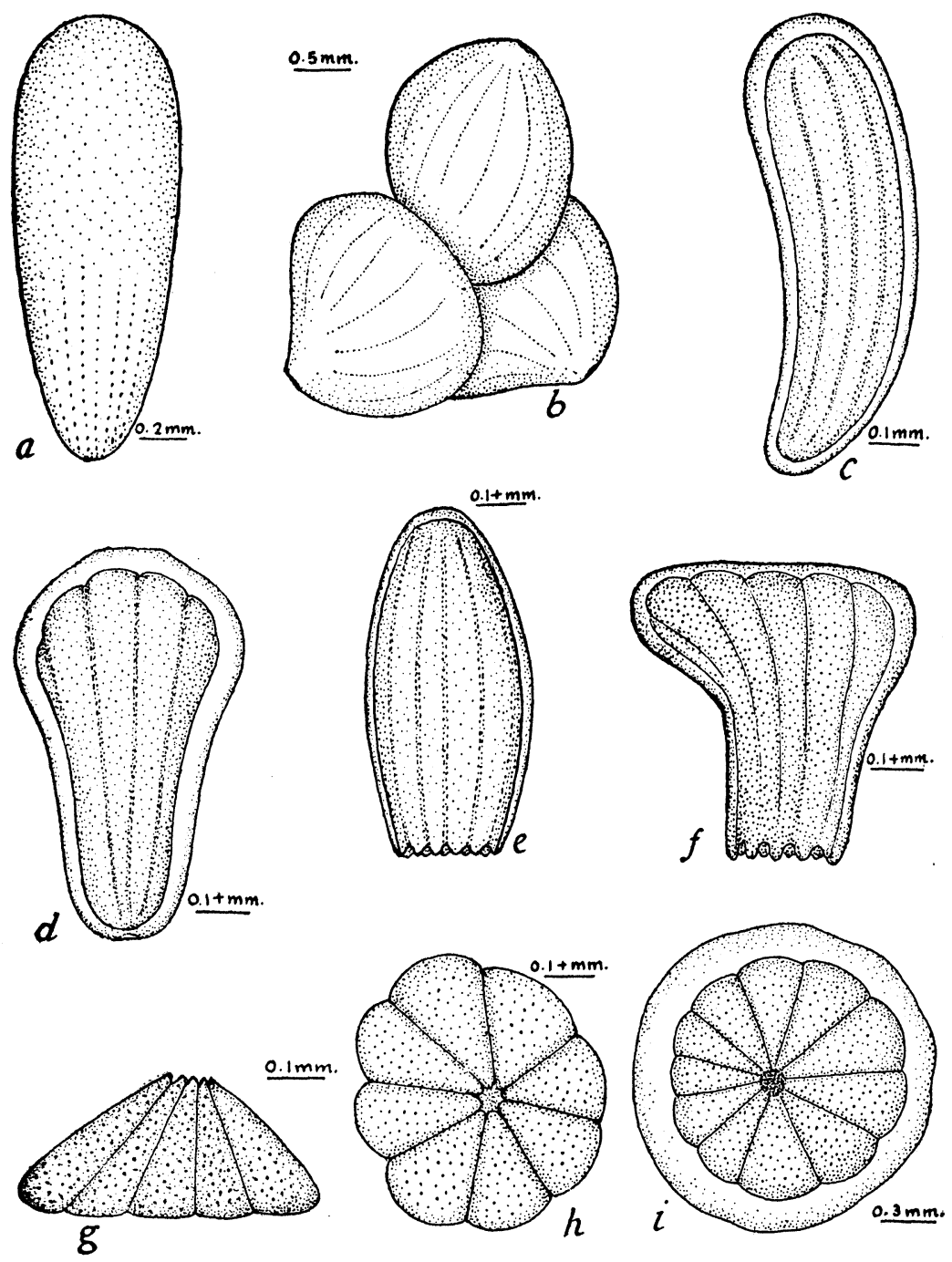

FIGURE 1.- $a-b$, Planula of Dendrophyllia manni: $a$, on release from polyp; $b$, united while free swimming- $c-i$, planulae of Pocillopora cespitosa: $c$, soon after release from polyp ; $d, 18$ days old, oral aperture formed; $e$-f, each 15 days old, with tentacles forming ; $f$, slightly contracted; $g, h$, lateral and oral views of a strongly contracted specimen; $i$, oral view of contracted specimen with 11 tentacles forming. 
MacMunn (11) found, in addition to pigments in the tissue of the polyps, a dark coloring matter extractable from the decalcified corallum of Dendrophyllia ramea and other corals of the Maldives. The pigments decreased as the bathymetric range of the corals increased, serving, according to that investigator, as a screen against ultra-violet rays of light.

In Kaneohe Bay Dendrophyllia manni thrives well under ledges of rock or in positions where light is subdued. It has also been shown that planulae of the species readily become affixed and young polyps grow in total darkness. (See p. 12.)

Like other planulae observed, those of Dendrophyllia are positively phototropic when first expelled. This response, however, is not long sustained, as the organisms settle, usually within a few days, to the bottom of the container, where the light is less intense. There they continue their activity until they become affixed or die.

The fusion of planulae of $D$. manni while in the free-swimming state has frequently been observed. A union of the lateral or aboral surfaces of two or more organisms may occur (fig. $1, b$ ), the activity of the resultant mass being marked by very erratic movements.

Planulae of this species are known to settle in clusters, becoming attached in a crowded manner with the borders of adjacent polyps touching each other. (See fig. 3, b.) A mutual attraction is apparently exhibited by the planulae during the process of settling and fixation. Duerden (3) mentions similar phenomena in Siderastrea radians and other corals. The adherence of settling planulae, which I have observed also in Cyphastrea ocellina, probably occurs more often under laboratory conditions than in the sea, where the organisms are not so closely confined and have less chance for contact with each other. Should the phenomenon occur under natural conditions, it is obvious that a coral colony would develop more rapidly than if it originated from a single planula.

Although Pocillopora cespitosa is one of the common corals of Hawaii, I have had little opportunity of studying its planulae. Only once have I observed colonies of this species expel planulae, that being under laboratory conditions during the month of January.

When released by the polyp the planula of Pocillopora cespitosa is oval or club-shaped, the aboral end, usually the broader, preceding when the organism is in motion. Large specimens reach a length of $1.5 \mathrm{~mm}$. Algal cells crowding the interseptal areas are responsible for the brown, longitudinal striations by which the organism is characterized. Lighter septal lines alternate with the more deeply colored stripes. The clear ectoderm is sharply contrasted with the brown color of the entoderm. (See fig. 1, $c$ and $d$.) 
After exhibiting positive phototropism for a few days the planulae settle to the bottom of the container and creep about, by the action of cilia, until affixation occurs. Tentacles may appear in this planula, as in that of Cyphastrea ocellina, while the organism is still free swimming. (See fig. 1, $e, f$.)

Planulae of Pocillopora settled and attached themselves in from 3 to 18 days to pieces of broken glass, cement blocks, filaments of algae, and to the smooth surface of glass containers in which they were kept. Following the affixation of the planulae the young polyps were developed in circulating sea water in the laboratory.

Skeletal material is developed rapidly in the early phase of this polyp. A basal plate, from which arise the calicular wall and septal ridges, makes its appearance immediately following the affixation of the planula. In from 10 to 20 days the polyp may have attained a diameter of $2 \mathrm{~mm}$. (See fig. 3, c, d.) As the primary and secondary septa are formed, tall, sharp pillars are deposited at intervals on their upper free edges, making substantial supports for the polyp. The pillars rise above the wall of the calicle and are clearly visible through the living tissue of the animal. (See fig. 3,e,f.)

Although the typical number of tentacles of the species is 12 , this number is seldom seen in a young polyp up to 2 months of age. At first the number may vary from 7 to 11 , the complete series being reached later by a subdivision of one or more of those already present.

In the specimens observed, the first bud (daughter polyp) varied in time of appearance from 15 to 55 days. (See fig. 3, d,e.) At 6 months of age colonies developed from 10 to 12 buds (Pl. IV, $A$ ), and this average of 2 buds a month was usually maintained during the first year. The specimens which grew best in the laboratory produced from 20 to 25 polyps and deposited about $150 \mathrm{c}$. $\mathrm{mm}$. of skeletal material in 12 months.

In my investigations planulae of Cyphastrea ocellina were used more extensively than others because of the ease with which they were procured.

A ready method of obtaining planulae of this species was found by raising the temperature of the water from $5^{\circ} \mathrm{C}$. to $10^{\circ} \mathrm{C}$. above normal. Almost without exception, throughout the year, colonies of $C y p h a s t r c a$ were caused to release planulae either by slowly heating the water surrounding the corals to approximately $35^{\circ} \mathrm{C}$. or by plunging specimens into water at about that temperature. Occasionally plantlae were produced at $31.5^{\circ} \mathrm{C}$. but more commonly at from $33^{\circ} \mathrm{C}$. to $35^{\circ} \mathrm{C}$. A maintenance of the temperature at $35^{\circ} \mathrm{C}$. for an hour was, at times, required for the release of the planulae. This prolonged heating kills adult corals but does not injure the planulae. In a colony of approximately 1850 polyps 600 planulae were released by the heat method in a few minutes. That such extreme thermal conditions, however, are means of forced expulsion of planulae is apparent when many thus given off are seen to be subnormal in size. 

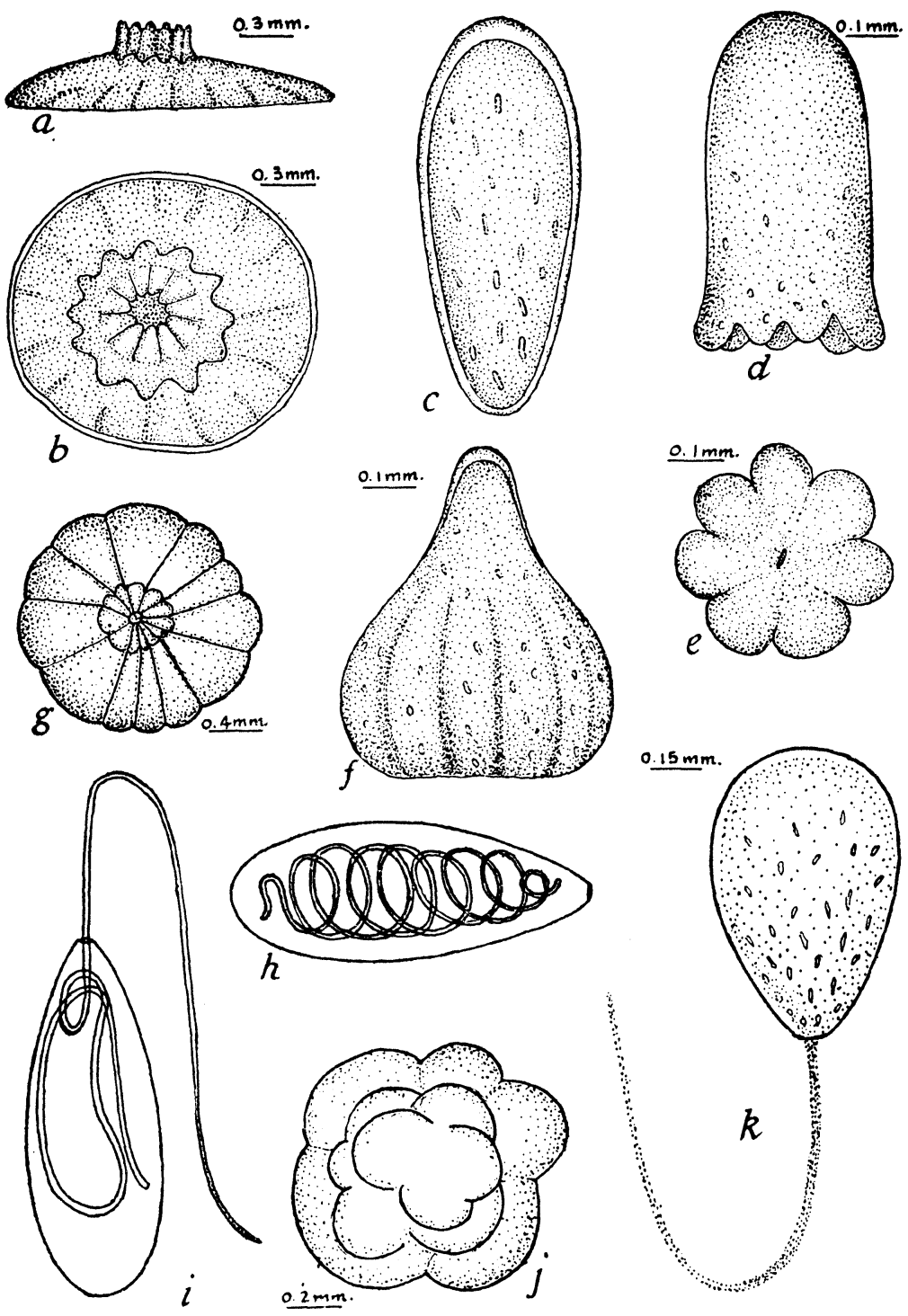

FIGURE 2.- $a, b$, Lateral and oral views of polyp of Pocillopora cespitosa, 15 days old-c-f, planulae of Cyphastrea ocellina: $c$, on release from polyp; $d, e$, lateral and oral views of specimen with 7 tentacles forming; $f$, contracted specimen- $g$, polyp of $C y$ phastrea ocellina with 12 tentacles, 3 days old- $h, i$, nematocysts of planula of Cyphastrea ocellina, undischarged and partially discharged, highly magnified- $j$. lobulated planula of Cyphastrea ocellina after 1 hour at $5^{\circ} \mathrm{C}$. - $k$, contents of gastric cavity of planula of Cyphastrea ocellina escaping from oral aperture. 
It is probable that planulae of this species swarm naturally in the sea when the temperature of the water approaches a maximum. The temperature of the Hawaiian reef water, under normal conditions, does not reach $35^{\circ} \mathrm{C}$. or even $33^{\circ} \mathrm{C}$. However, as shown in a previous paper (7), a temperature of $31.5^{\circ} \mathrm{C}$. may be reached within 50 feet of the shore, and on a hot afternoon, at low tide, this species is probably exposed to temperatures as high as $30^{\circ} \mathrm{C}$. for several hours' duration.

Planulae of Cyphastrea have also been caused to swarm by permitting the adult colonies to remain in stagnant sea water for 26 hours. This treatment kills the adults but the planulae are uninjured. Planulae have also swarmed in dilute sea water ( 2 parts of sea water to 1 part of fresh water) and in concentrated sea water of about 110 per cent.

High temperature; stagnant sea water, accompanied by increased acidity; dilute and concentrated sea water are some of the factors responsible for the release of planulae of Cyphastrea ocellina while under laboratory control. It seems that conditions inimical to the life of the parent colony hasten the development of planulae as a safeguard for the preservation of the species. Many extreme situations fatal to adults have no such effect upon the planulae.

In general form and size and in manner of movement the planulae of Cyphastrea ocellina resemble those of Pocillopora cespitosa. The brown color is due to algal cells within the endoderm, but distinctive markings consist of numerous, minute, pearl-white bodies in the ectoderm, either scattered throughout or massed near the oral end. (See fig. 2, c.) These refractive bodies, of doubtful nature, maintain their entity under abnormal conditions. In the absence of light the chlorophyl of the infesting algal cells may disappear, leaving the planulae colorless, but the pearl-white bodies remain distinctly outlined.

Planulae sectioned just after being extruded from the polyps do not show the presence of an oral aperture, but the interior is seen to be an almost solid mass of clear cells with zooxanthellae dispersed among them. (See fig. 4, a.) Duerden (2) has shown the internal development of the larva of an actinian, Lebrunia, which parallels, in many respects, the features seen in the planula of Cyphastrea ocellina.

Before the oral aperture is formed, which usually occurs within 24 hours, the first pair of mesenteries begin their development from the entodermal lining of the gastric cavity. (See fig. 4, b.) Rapid development follows, and as soon as the mouth is formed the gastric cavity becomes enlarged by the breaking away of entodermal cells, which stream out of the oral aperture as the planula moves forward. (See fig. 2,k.) On formation of the mouth the ectodermal cells are carried downward as the lining of the gullet 
(fig. $4, e$ ), and some sections seem to show a fusion of this tissue with the mesenteries.

The ectoderm is relatively thick, being composed of slender columnar cells and densely packed with nematocysts. Interspersed among the epithelial cells are large, oval bodies, which stain deeply with haematoxylin and probably are glands. At the inner border of the epithelial cells is a narrow zone consisting of nerve elements, and next the entoderm is a basal membrane with contractile fibers. Between nerve layer and muscles is the mesogloea. (See fig. $4, f$.)

At the aboral end of a well-developed planula of Cyphastrea ocellina is a thickening of the nerve layer forming a cap at the base of the ectoderm. Here the layer is about 4 times as thick as in other regions of the planula. (See fig. 4, d.) Duerden (2) noted an exceptionally well-developed nerve layer about the aboral end of the larva of Lebrunia and believed greater sensitiveness was shown at this extremity, which precedes during movement. McMurrich (13) observed a similar thickening of the nerve layer at the aboral end of the embryo of Rhodactis.

Nematocysts are abundant in the ectodermal layer of the planula of Cyphastrea when released from the polyp. They are unequally developed, the smaller, immature ones being more numerous than the mature ones. Before being discharged the hollow thread is loosely coiled within the cell and on being discharged is expelled through a pore at the narrow end. The cell and thread are smooth, no trigger or barbs being observed. (See fig. $2, h, i$.)

Tentacles often make their appearance in the planula of Cyphastrea ocellina before the organism becomes affixed. The initial number may vary from 7 to $12-12$ being typical for the species. I have observed additional tentacles being formed by subdivisions of those already present.

A wide range of duration of the free-swimming period of planulae of this species was observed. Some remained unattached for nearly a month; one with the typical number of tentacles became affixed in 3 days. (See fig. 2, g.)

Subsequent to affixation of the planula the normal growth of Cyphastrea ocellina is slow, especially in its early stages, as compared with Pocillopora cespitosa. A long time is required for the appearance of the first bud (daughter polyp) in Cyphastrea, whether the development occurs in the sea or under laboratory conditions.

A polyp grown in the laboratory, resulting from a planula affixed November 24, did not produce the first bud until March 14, following. Another polyp attached November 7 did not bud during the first 4 months, but produced 2 buds by March 19. In Pocillopora cespitosa from 4 to 6 buds are developed in an equal time. (See p. 8.) 
The rate of growth of Cyphastrea ocellina in the laboratory compares favorably with its development in the sea. During a period of 8 months, June to February, a colony arising from a single planula and grown in the laboratory developed 14 polyps, and an equal number was produced in 9 months, March to December, in a colony placed 450 feet from the shore on Waikiki reef, immediately after the affixation of the planula. Another laboratory-grown colony developed 21 polyps, and deposited $300 \mathrm{c}$. mm. of skeletal material the first year, which was $50 \mathrm{c}$. mm. more than that laid down in the same period under natural conditions in the sea by a young colony 2 or 3 years old at the beginning of the experiment. This same laboratory-grown colony developed 27 polyps in 18 months.

Little is known regarding the factors responsible for the affixation of planulae following a period of free existence. Vaughan (16) observed that planulae usually settled in from 1 to 21 days after being released from the polyps. My experience with the planulae of Hawaiian corals is that the freeswimming period varies greatly, the organisms settling and becoming fixed, however, under laboratory conditions within 30 days, if at all.

The total absence of light seems to have little or no influence on the capacity of planulae of Dendrophyllia to become attached. In darkness they settle and become fixed as readily as in control experiments subjected to normal light. Of two lots in total darkness 100 per cent became attached within 30 days, and some of the resulting polyps continued to grow with light excluded for 7 months. Although growth was slow during this period and the orange color was gradually lost, some of the polyps developed one or two buds and considerable skeletal material was laid down. The ultimate death of these specimens was probably due to lack of nourishment as no artificial feeding was attempted.

The accommodation of planulae of Dendrophyllia manni to darkness may be correlated with the fact that this species under normal conditions in the sea thrives well in subdued light. (See p. 7.)

Most planulae of Cyphastrea ocellina do not become affixed so readily in sustained total darkness as under normal conditions. Although in some experiments about 50 per cent settled and became affixed with light excluded, in others no planulae became attached within 60 days.

Young polyps of Cyphastrea affixed and grown in constant total darkness do not show the same vigor and tenacity of life as those of Dendrophyllia manni under similar conditions. The explanation of this may be that adult colonies of Cyphastrea live in more shallow water and are subjected to a greater intensity of light than those of Dendrophyllia.

A constant temperature of about $5^{\circ} \mathrm{C}$. above the average to which the adult species is normally subjected does not seem to retard the affixation 

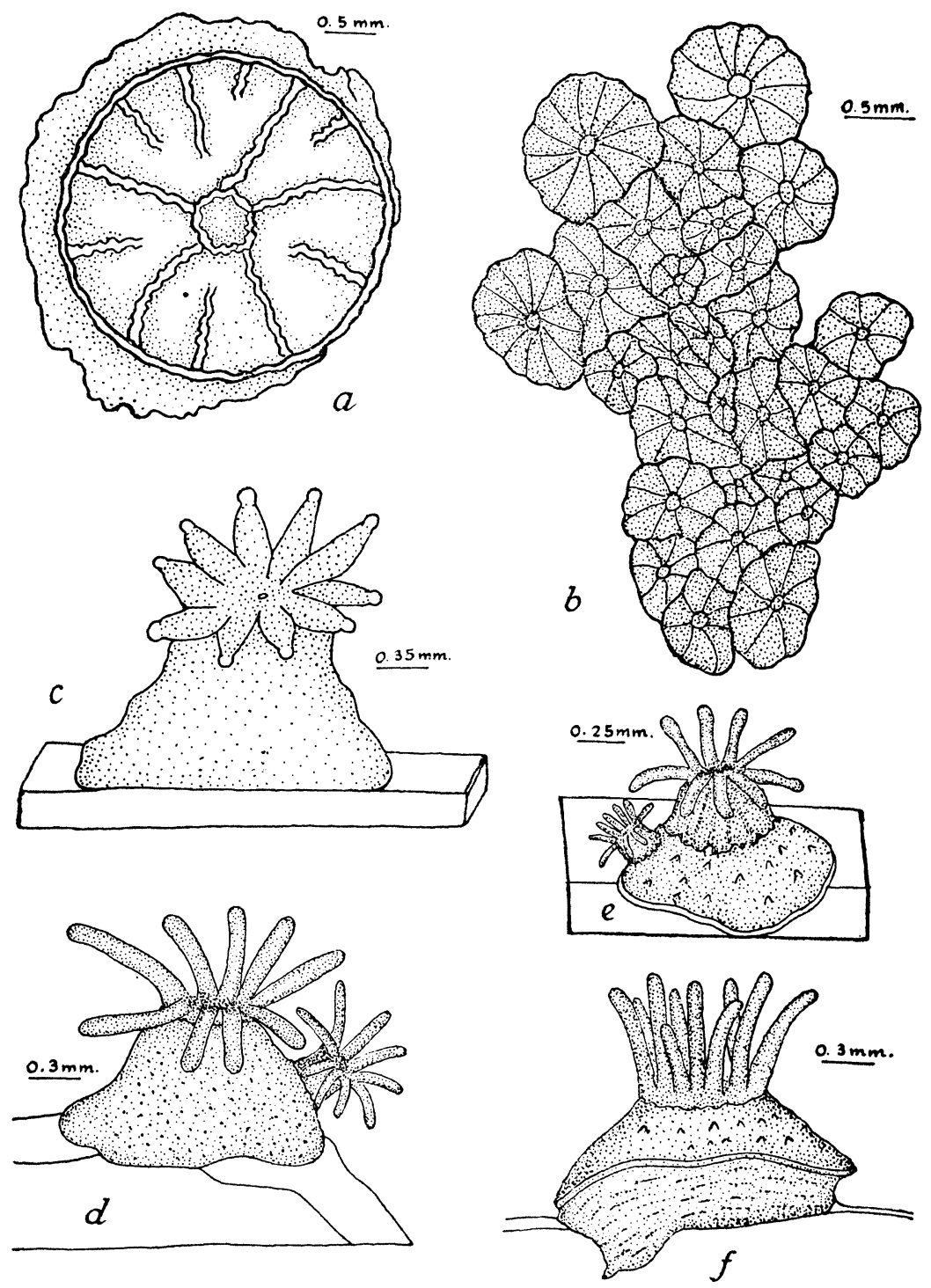

FIGURE 3.- $a$, Skeleton of Cyphastrea ocellina formed in 79 days- $b$, polyps of Dendrophyllia manni resulting from aggregated settling of planulae-c-f, polyps of Pocillopora cespitosa, 21 days, 19 days, 53 days, and 33 days old, respectively; $d$, e, each show a first bud. 
of planulae of Cyphastrea ocellina. Planulae readily become attached and begin to deposit skeletal material at temperatures varying from $30.5^{\circ} \mathrm{C}$. to $31^{\circ} \mathrm{C}$., but are not able to endure these thermal conditions long. In an extensive series of experiments 50 per cent of the planulae became fixed within 3 days, but none of the young polyps or free planulae lived longer than 7 days. In one lot of 12 planulae at a constant temperature of $31^{\circ} \mathrm{C}$., 50 per cent became attached in 24 hours, whereas in the same number as a control, at normal temperature of the laboratory water, about $26^{\circ} \mathrm{C}$., none became fixed. Metabolic processes responsible for the settling and attachment of the organisms seem to be hastened by the increased temperature, although it eventually proves fatal.

Experiments were conducted to determine to what extent planulae will settle and become attached in various dilutions of sea water. Planulae of Dendrophyllia manni readily became fixed in a solution of 9 parts of sea water to 1 part of fresh water. In this solution, changed daily, young polyps were grown for 7 months. During this time no artificial feeding occurred, the only nourishment being derived from the noncirculating, dilute sea water. The starved condition of the polyps was clearly shown in the form of the skeleton deposited. Instead of a cylindrical calicle, as in a normal polyp, a truncated, conical one was formed, the polyp at the end of 7 months being about one-half its original diameter.

Planulae of Dendrophyllia also became fixed in a solution of 3 parts of sea water to 1 part of fresh water. Young polyps lived 6 months with this solution changed daily and no artificial feeding. A well-formed basal plate, a calicle wall, and primary and secondary septa were deposited. Only slight upward growth, however, of the wall and septa occurred.

In a still more dilute solution, 2 parts of sea water to 1 part of fresh water, planulae of Dendrophyllia rarely became attached. In one experiment, however, three planulae attached themselves to the smooth surface of the glass container and lived for 165 days with the solution changed daily and without artificial feeding. A complete basal plate was laid down but only traces of septa and a calicle wall appeared.

When the salinity of the medium was further reduced, 1 part of sea water to 1 part of fresh water, planulae of Dendrophyllia showed no disposition to become attached but most of them died within 7 days.

Planulae of Cyphastrea, however, are more resistant to reduced salinity, having lived for 25 days in sea water diluted with an equal part of fresh water. About 10 per cent of the planulae became attached, but mere traces of skeletal material were deposited in the form of basal plates. The polyps thus formed were subnormal, did not develop tentacles, and died in about a week. 
Planulae of Dendrophyllia readily became attached in sea water with the hydrogen ion concentration altered from $\mathrm{pH} 8.5$ to $\mathrm{pH} 7.0$, and they continued to live for more than 5 months with the neutral solution changed daily and without artificial feeding. Slight skeletal material was depositer by the polyps during this time, approximating in amount that laid down in a similar period in sea water, two parts of which were diluted with one part of fresh water. (See p. 14.)

In sea water of neutral $\mathrm{pH}$, plantlae of Cyphastrea became attached and lived for 4 months without artificial feeding. Much more skeletal material was deposited than by Dendrophyllia under similar conditions. Primary and secondary septa were well formed in 30 days, and the polyps showed a healthy condition for the first two months.

Planulae of both Dendrophyllia and Cyphastrea when transferred from normal sea water to fresh water die at once, contracting into spherical bodies. The ectoderm, which appears as a thick, clear zone at the periphera, soon disintegrates, leaving a highly lobulated mass of entoderm.

Numerous experiments were made to determine whether planulae will become affixed at temperatures from $5^{\circ} \mathrm{C}$. to $10^{\circ} \mathrm{C}$. lower than normal. No planula of Dendrophyllia manni or Cyphastrea ocellina became affixed while exposed to temperatures ranging from $16^{\circ} \mathrm{C}$. to $14^{\circ} \mathrm{C}$. They do not long survive such a cooling process. Planulae of Cyphastrea may recover after 48 hours and those of Dendrophyllia are slightly more resistant, but continued exposure invariably results in a shriveled condition of the organisms, and on being returned to normal temperature they soon disintegrate and die. In one experiment after planulae of $C y$ phastrea were subjected to temperatures from $16^{\circ} \mathrm{C}$. to $14^{\circ} \mathrm{C}$. for 18 hours they were returned to normal temperature, and many of them became attached within 8 days without showing detrimental after effects.

TABLE, 1. COMPARATIVE RESISTANCE OF PLANULAE OF DENDROPHYLLIA MANNI AND CYPHASTREA OCELLINA TO RAPID REDUCTION OF TEMPERATURE $\left(25^{\circ} \mathrm{C}\right.$. AN HOUR $)$.

From normal

( $25^{\circ}$ C. $)$ to :

$20^{\circ} \mathrm{C}$.

$10^{\circ} \mathrm{C}$.

$5^{\circ} \mathrm{C}$.
Dendrophyllia manni

Very active movements

No movement ; recovered on return Co to normal temperature

Contracted ; no movement ; recovered; normal in 24 hours
Cyphastrea ocellina

Normal activity

Contracted and shriveled; slight rotary movement; dead within 8 days on return to normal temperature

Shriveled and lobulated; dead within 6 days 


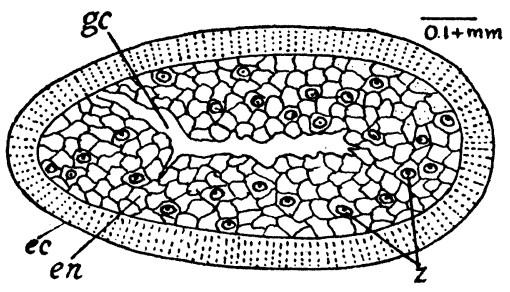

$a$
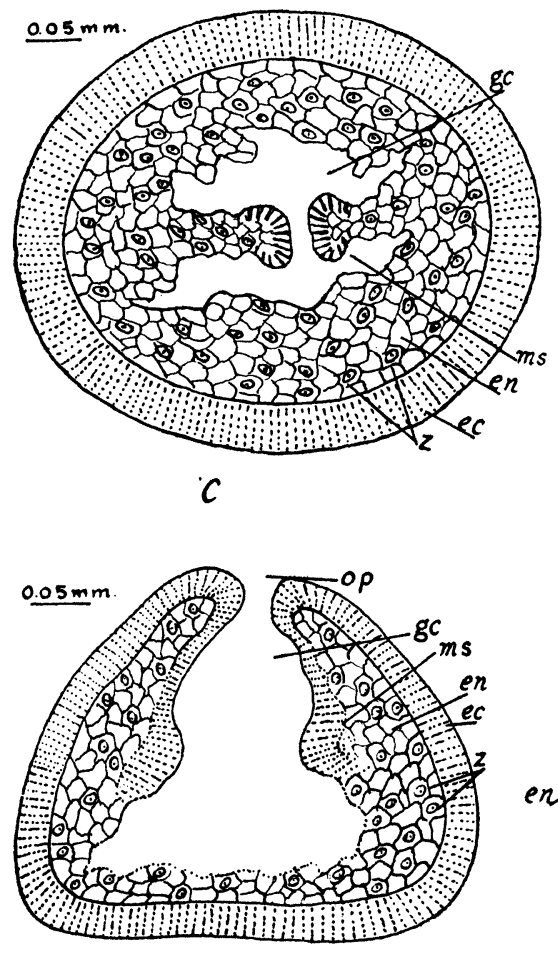

e

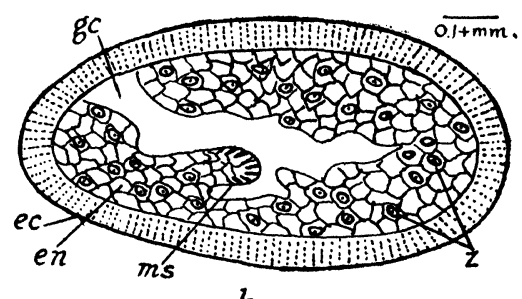

$b$

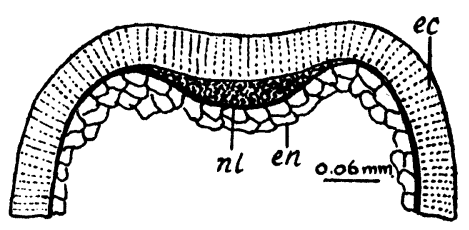

$d$

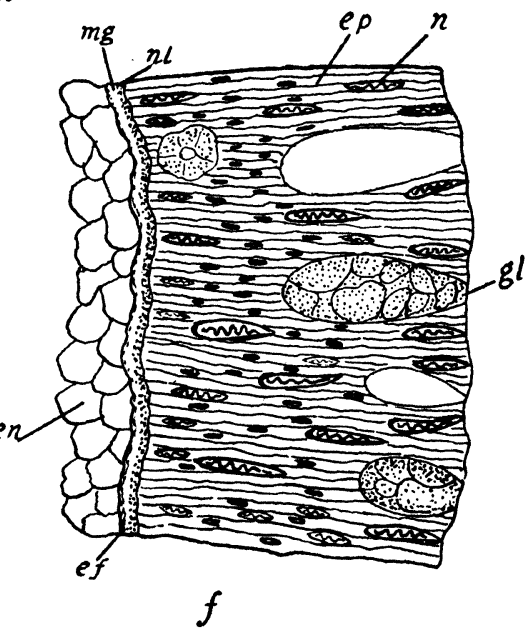

FigURE 4--Sections of planulae of Cyphastrea ocellina: $a, b$, longitudinal sections of an early and later stage $-c$, cross section through first pair of mesenteries $-d$, section through aboral extremity showing thickened nerve layer-e, longitudinal section through oral aperture- $f$, section of wall of planula, highly magnified: $e c$, ectoderm; $e f$, elastic fibers; $e n$, entoderın; $e p$, epithelium; $g c$, gastric cavity ; $g l$, gland ; $m g$, mesogloea ; $m s$, mesentery; $n$, nematocyst; $n l$, nerve layer; $o p$, oral aperture; $z$, zooxanthellae. 
When subjected to rapid cooling, planulae of Dendrophyllia may recover after $5^{\circ} \mathrm{C}$. has been reached, when returned to normal conditions, whereas those of Cyphastrea will not endure much less than $10^{\circ} \mathrm{C}$., becoming lobulated and most of them dying within a few days. (See fig. 2, $j$, and Table 1.) Planulae of Cyphastrea are, however, more resistant to a rapid rise of temperature than are those of Dendrophyllia. (See Table 2.)

TABLE 2. COMPARATIVE RESISTANCE OF PLANULAE OF DENDROPHYLLIA MANNI AND CYPHASTREA OCELLINA TO RAPID RISE OF TEMPERATURE.

From normal $\left(25^{\circ}\right.$ C. $)$ to :

$\begin{array}{ll}35^{\circ} \mathrm{C} . & \text { Contracted ; normal activity } \\ 38^{\circ} \mathrm{C} . & \text { Contracted ; slight movement } \\ 39^{\circ} \mathrm{C} . & \begin{array}{l}\text { Iontracted ; no activity ; recovered } \\ \text { quickly on return to normal } \\ \text { temperature }\end{array}\end{array}$

$40^{\circ} \mathrm{C}$. Contracted; shriveled; dead

$41^{\circ} \mathrm{C}$. Dead

Dendrophyllia manni
Cyphastrea ocellina

Contracted; normal activity

Contracted ; slight movement

Contracted; no movement ; recov* ered at once on return to normal temperature
Contracted; no movement ; recov- ered on return to normal tem- perature

Strongly contracted; no movement; recovered; normal in 24 hours

On comparing the resistance of planulae and adults to a rapid rise of temperature it was found that the planulae of both Dendrophyllia and Cyphastrea endure heating better than do the adults. Adults and planulae of Dendrophyllia were plunged into water at $38^{\circ} \mathrm{C}$. In 30 minutes the adults were dead, but the planulae survived for 45 minutes. On being subjected to a temperature of $35^{\circ} \mathrm{C}$. for 24 hours the adults of Dendrophyllia died, but the planulae survived.

Planulae and adults of Cyphastrea were exposed to a temperature of $36.5^{\circ} \mathrm{C}$. for 24 hours. The planulae survived, but the adults died. Exposure for 48 hours at this temperature proved fatal to the planulae.

A variety of experiments indicates that planulae of corals are more highly resistant than adults of the same species to many abnormal conditions other than high temperature. (See page 10.)

In a previous paper (7) I showed that the planulae of Cyphastrea ocellina, although adapted to higher temperatures than the adults, do not stand cooling below $10^{\circ} \mathrm{C}$. so well as do the adults. 


\section{PREVIOUS RECORDS OF CORAL, GROWTH}

INDIAN OCE,AN

Guppy (9) at Cocos (Keeling) Islands estimated the branching madrepores (Acropora and Montipora) to increase in height at the annual rate of 4 or 5 inches, reaching their full growth in about 15 years. According to his observations, branching Porites grew vertically about $1 \frac{1}{2} 2$ inches per year, and massive Porites gained in height half an inch to three-fourths of an inch annually. Of two massive specimens of Porites, each weighing originally from 5 to 7 pounds, one increased in 15 years to 125 pounds and the other to 278 pounds.

Wood-Jones (17), also at Cocos (Keeling) Islands, estimated the upright growth of branching madrepores at about 3.7 inches a year. Massive forms added about one-thirty-seventh of their original circumference in 100 days.

Gardiner (10) at North Male atoll, Maldives, estimated the annual gain in height of massive forms as about $23.6 \mathrm{~mm}$. and of branching corals $35 \mathrm{~mm}$. His records were based on a growth period that he supposed to be somewhat less than 3 years.

\section{PACIFIC OCEAN}

Finckh (8) at Funafuti records the vertical growth of Montipora incognita as 1 inch in 35.7 weeks, and states that Pocillopora grandis expanded 1 inch in 13.5 weeks. A fragment of Pocillopora verrucosa increased in weight 150 per cent in one year, and a specimen of Porites limora, weighing 22 pounds, increased in weight during a period of 4 months at the rate of 42.27 per cent a year.

Mayor (12) at Samoa found the average annual gain in height and weight for various forms of corals as follows:

$\begin{array}{lcc}\text { Acropora } & \begin{array}{c}\text { Height } \\ \text { (Millimeters) }\end{array} & \begin{array}{c}\text { Weight } \\ \text { (Grams) }\end{array} \\ \text { Pocillopora } & 30 & 501 \\ \text { Branching Porites } & 23 & 272 \\ \text { Massive Porites } & 30 & 222 \\ \text { Pavona } & 17 & ? \\ \text { Psammocora } & 32 & 34 \\ \end{array}$

On the basis of the increases shown, Mayor estimated that a layer of coral $8 \mathrm{~mm}$. thick would form over the entire reef annually, the amount being about the same as that worn away each year.

In 1913 Mayor re-measured some of the massive corals marked by Saville-Kent at Thursday Island, Torres Strait, in 1890. The estimated annual increase in diameter was $46 \mathrm{~mm}$. to $49 \mathrm{~mm}$. 


\section{ATLANTIC OCEAN}

Vaughan (15) recorded the growth of corals at Golding Cay, Bahamas, and at Dry Tortugas, Florida. One of the typical species, Orbicella annularis, showed an average annual vertical growth at Golding Cay of $5.7 \mathrm{~mm}$., based on 5 specimens in 2 years' time. At Dry Tortugas the annual rate for this species was $5.28 \mathrm{~mm}$., based on the same number of specimens and for the same length of time. At the Bahamas 5 specimens of Acropora palmata in 2 years' time made an average annual gain in height of $24.4 \mathrm{~mm}$. Attached to tiles at Fort Jefferson, Dry Tortugas, a branching form, Porites clavaria, showed an average annual increase in height of $20.45 \mathrm{~mm}$., based on 21 specimens. At Golding Cay the same species averaged $20.25 \mathrm{~mm}$. Massive forms of Porites asteroides on tiles at Fort Jefferson averaged $5.70 \mathrm{~mm}$. in annual vertical growth, whereas one specimen naturally attached grew 14 mm., and on Loggerhead Key 7 specimens naturally attached averaged $13.28 \mathrm{~mm}$. a year. At Golding Cay the same species on tiles averaged 3.50 $\mathrm{mm}$. in vertical growth, whereas 4 specimens naturally attached averaged $8.75 \mathrm{~mm}$.

Vaughan records a total increase in weight of 5 specimens of Orbicilla anmularis at Golding Cay of 59.1 per cent in 2 years. During the same period 5 specimens of Acropora palmata gainer 231.8 per cent in weight.

Although Mayor's report on coral growth at Samoa was not available when the records were made in the Bahamas and Florida localities, Vaughan concluded that massive corals grew more rapidly in the Indian and Pacific oceans than in the Atlantic. Mayor's observations at Samoa support this conclusion, at least with regard to certain areas of the Pacific Ocean.

\section{METHODS OF WORK}

To ascertain the rate and amount of growth in Hawaiian shallow-water corals two principal lines of investigation were followed. The annual vertical growth was estimated by careful measurements, and gains in weight were tabulated through definite periods of time.

Various methods were employed for estimating the rate of vertical growth. The system applied by Vaughan (16) was used in part. Circular cement blocks 8 inches in diameter, each with a hole in the center, were made and living coral colonies set in the block while it was still soft. A noncorrosive metal plate set in the cement at the foot of each coral head served as a measuring base. When the cement block was hardened it was slipped over the end of an iron stake driven into the reef and securely fastened to it. When in place, the blocks with corals attached rested 1 to 2 feet above the surface of the reef.

Other corals were set in blocks of soft cement, not too large to handle 
but having considerable weight. When hardened, these blocks were placed on the floor of the reef, depending upon weight and position to prevent their being moved by waves.

Specimens of Fungia and small colonies of other species were successfully handled in heavy galvanized wire baskets set in cement blocks. This method had the advantage of preventing, to some extent, the destructive effects of seaweeds. The galvanized wire netting stood up well for as long as three years. For measuring vertical growth a combination square, graduated in units of 64 to an inch, with level attached, was used.

Some corals were raised from the planulae and kept under observation in the laboratory for $1 \frac{1}{2}$ years. Others were placed in the ocean on the affixation of the planulae and the progress of their growth noted.

To ascertain increase in weight, after being taken from the ocean and thoroughly shaken to rid them of as much water as possible, corals were weighed and wired to gas pipes suspended horizontally in the sea between iron stakes. The copper wire, by means of which a colony was supported, was also weighed and a deduction made in the final reweighing of the coral, as the wire was usually imbedded by overgrowth and not capable of being removed.

A number of heavy colonies, unattached but in place, were weighed and the increases recorded through a period of more than two years.

A number of laboratory experiments were conducted to test the effect of such abnormal conditions as altered salinity, hydrogen ion concentration, and light on the growth and weight of corals. Careful selection of coral colonies to be used for determining increased height and weight was made in the first place, and on recording results all specimens showing serious external attacks by algae, partially dead, broken, or otherwise defective were discarded. All weight increases were recorded by the same balance, which was sensitive to 0.1 gram.

\section{GROWTH-RATE OF HAWAIIAN CORALS}

It is unusual to find corals growing steadily and constantly through a long period. Rapid growth alternates with inactivity but with no degree of regularity. While one colony is making a remarkable gain, another near by, of the same or a different species, may make little or no progress. Wood-Jones (17) found species of Madrepora growing most rapidly while colonies of Porites under identical conditions were most inactive, and vice versa.

Among 44 specimens of Pocillopora meandrina var. nobilis on Waikiki reef, during 131 days the range of vertical increase was from $0.4 \mathrm{~mm}$. to $10.5 \mathrm{~mm}$. (Table 9). All were nearly equal in size when the experiment began, in close proximity, and subjected to similar ecological conditions. 
When compared by weight similar variations occur. A colony of Pocillopora ligulata weighing 34.2 grams added 3.6 grams (10.5 per cent) in 104 days; one weighing 21.5 grams added 15.9 grams ( 73.8 per cent), and one weighing 40.9 grams added 62.7 grams (153.4 per cent) during the same time and under similar conditions.

Slight seasonal variations in temperature of the reef water in Hawaii obviously have no influence on the rate of growth of corals. Some colonies have shown greater activity during the cooler season of the year, from December to March, than in a 3-months' period when the temperature is slightly higher, but others of the same species have shown a more rapid growth during the warmer months of the year.

An abundant food supply is doubtless an important factor in stimulating growth in corals as in other organisms. Although I have shown that corals may live several months in dilute sea water, lacking normal food, and even in filtered sea water, there is a very noticeable loss of weight under such conditions. (See p. 35.)

Daily hauls with a tow net on Waikiki reef indicate that the zooplankton upon which corals normally feed is variable in kind and quantity from day to day. I have observed the surface water at night to have a greater abundance and assortment of minute animal organisms than during the day. Corals probably feed more freely at night, as polyps in the laboratory show greater activity at that time than during daylight.

As Mayor (12) pointed out, many early accounts of the rate of growth of corals were vague and lacked precision, making it impossible to place full confidence in them. Due to inexact information the growth period often was assumed, or the rate of increase was recorded from casual observation. Many early records, as reviewed by Darwin (6) and by Dana (5), announce remarkable coral growth far in excess of any recent results obtained by actual measurement.

During the past 30 years increasing interest in the general problem of reef formation has resulted in more exact observations of the rate at which corals grow. Through the work of Gardiner (10) at the Maldives, of Guppy (9) and Wood-Jones (17) at Cocos (Keeling) Islands, of Finckh (8) at Funafuti, of Vaughan (15) at the Bahamas and Dry Tortugas, and of Mayor (12) at Samoa, considerable knowledge has accumulated from which definite conclusions have been reached regarding the rate of coral growth in those particular localities.

Investigations of the growth of Hawaiian shallow-water corals have been continuous since 1922, all records here presented having been collected about the island of Oahu.

Of the localities where previous studies of this kind have been made, all are more tropical in position than Oahu, with the exception of Golding 
Cay, Bahamas, and Dry Tortugas, Florida. With respect to the density of population of living corals and the vigor of their growth, the Hawaiian reefs obviously, more nearly resemble those of the Atlantic Ocean than of the Indian or Pacific Ocean in regions from which reports have come.

Among corals, species of Porites have probably contributed most to the formation of Hawaiian reefs. The genus was well represented in number of species when the present elevated reefs were submerged and is the predominating one among the living corals. According to Vaughan (14) 40, or more than half of all Hawaiian corals reported between 1 and 25 fathoms, are species or divisions of the genus Porites. In the first fathom of water on the reefs of Oahu 24 species and subdivisions of the genus are known.

Species of compact corals form stable masses, the spaces between which may be filled with detritus and in time the general level of the reef raised. Branching forms may serve as constructive factors when their ramifications are bound together by calcareous algae, the entire mass, in place or in a fragmented condition, entering into the composition of the reef.

Previous records of the growth of species of Porites agree that branching forms increase in height more rapidly than massive ones. On comparing Mayor's estimates (p. 18) with those of Vaughan (p. 19) it is seen that both branching and massive forms of Porites obviously grow more rapidly in Samoa than in the Bahamas or Dry Tortugas.

My findings indicate that the rate of vertical growth of Porites in Hawaii conforms more closely with Vaughan's estimates for Atlantic Ocean localities than with Mayor's results in Samoa. (See pp. 18, 19 and Tables 3, 4, 7.)

Vertical measurements of massive forms of corals may represent with slight degree of accuracy the actual growth of colonies, because lateral and basal expansions may not always be taken into consideration. Moreover, an increase in height does not always represent an increase in volume of a specimen, as it may be recorded when a large basal portion of the colony has been destroyed by algae. However, in carefully selected specimens of the genus Porites a more accurate conception of the growth of a colony may often be realized by weight than by vertical measurement.

Of the massive forms of Porites in Hawaii, Porites evermanni is a common one. The average annual growth of $11.6 \mathrm{~mm}$. given in Table 3 is a conservative estimate for the species. The rate of growth of $2.3 \mathrm{~mm}$. in 34 days shown by one specimen (Table 3 ) is not likely to be maintained through a year, as records for other specimens indicate. The specimen at Kaaawa, windward Oahu, which made the greatest gain in weight (Table 5), was originally two colonies that grew together in the course of the experiment. Originally the two colonies weighed 235.9 grams; united, they increased by 642.4 grams in 738 days, or 134.7 per cent annually. 
TABLE 3. VERTICAL GROWTH OF PORITES EVLRMANNI AT WAIKIKI RFEF.

$\begin{array}{cccc}\begin{array}{c}\text { Period of } \\ \text { growth } \\ \text { (days) }\end{array} & \begin{array}{c}\text { Average increase } \\ \text { for period } \\ \text { (millimeters) }\end{array} & \begin{array}{c}\text { Average annual } \\ \text { increase } \\ \text { (millimeters) }\end{array} & \begin{array}{c}\text { Number } \\ \text { of } \\ \text { specimens }\end{array} \\ 280 & 5.8 & 7.6 & 2 \\ 227 & 3.1 & 5.0 & 1 \\ 369 & 1.5 & 1.5 & 1 \\ 53 & 1.5 & 10.3 & 1 \\ 131 & 3.9 & 10.9 & 1 \\ 81 & 4.2 & 18.9 & 1 \\ 313 & 12.0 & 14.0 & 1 \\ 34 & 2.3 & 24.6 & 1\end{array}$

Average annual vertical growth, $11.6 \mathrm{~mm}$., based on 9 specimens.

TABIE 4. VERTICAL GROWTH OF FORMS OF PORITFS LOBATA AT WAIKIKI REEF.

\begin{tabular}{|c|c|c|c|c|}
\hline & $\begin{array}{l}\text { Period of } \\
\text { growth } \\
\text { (days) }\end{array}$ & $\begin{array}{l}\text { Average increase } \\
\text { for period } \\
\text { (millimeters) }\end{array}$ & $\begin{array}{l}\text { Average annual } \\
\text { increase } \\
\text { (millimeters) }\end{array}$ & $\begin{array}{c}\text { Number } \\
\text { of } \\
\text { specimens }\end{array}$ \\
\hline Porites lobata forma infundibulum & $\begin{array}{l}397 \\
271 \\
953\end{array}$ & $\begin{array}{r}8.0 \\
5.8 \\
16.0\end{array}$ & $\begin{array}{l}7.3 \\
7.8 \\
6.1\end{array}$ & $\begin{array}{l}1 \\
8 \\
1\end{array}$ \\
\hline Porites lobata forma lacera & 402 & 11.0 & 10.0 & 1 \\
\hline $\begin{array}{l}\text { Porites lobata forma centralis } \\
\text { subforma alpha }\end{array}$ & 381 & 5.5 & 5.2 & 1 \\
\hline
\end{tabular}

Average annual vertical growth of Porites lobata forma infundibulum, $7.1 \mathrm{~mm}$., based on 10 specimens.

TABLE 5. INCREASE IN WEIGHT OF PORITES EVERMANNI.

$\begin{array}{cccccc}\text { Locality } & \begin{array}{c}\text { Period of } \\ \text { growth } \\ \text { (days) }\end{array} & \begin{array}{c}\text { Average } \\ \text { increase } \\ \text { for period } \\ \text { (grams) }\end{array} & \begin{array}{c}\text { Average } \\ \text { annual } \\ \text { increase } \\ \text { (grams) }\end{array} & \begin{array}{c}\text { Average } \\ \text { annual } \\ \text { increase } \\ \text { (per cent) }\end{array} & \begin{array}{c}\text { Number } \\ \text { of } \\ \text { specimens }\end{array} \\ & 313 & 12.4 & 14.9 & 19.3 & 2 \\ \text { Kaikiki reef } & 363 & 47.6 & 47.6 & 40.4 & 1 \\ & 196 & 185.1 & 344.3 & 20.9 & 3 \\ \text { Kaaawa reef } & 101 & 21.8 & 78.5 & 59.2 & 2 \\ & 738 & 642.4 & 317.9 & 134.7 & 1\end{array}$

Average annual increase in weight, 54.9 per cent, based on 9 specimens.

In the union of colonies of the same species the calicles of the two specimens merged and fused perfectly at the point of contact, gradualiy obliterating the suture (Pl. IV, E). Contrasted with this intimate union of colonies of the same species, the fusion of a form of Porites compressa with Porites evermanni results in a curved, compressed ridge formed by growth of both specimens, but no merger or blending of calicles (Pl. IV, B). As many as 5 specimens have united to form a single mass. Thus in the coral mass shown in Plate IV, D, Porites evermanni alternates with Porites com- 
pressa forma granimurata, but at all suture lines calicles of distinct species remain independent.

Colonies of Porites lobata forma infundibulum that I have measured ranged in vertical growth from about $7 \mathrm{~mm}$. to about $10 \mathrm{~mm}$. annually. One colony (Pl. IV,$C$ ) made a gain of $9 \mathrm{~mm}$. in 372 days, although it was severely attacked by algae. Another specimen increased $17.1 \mathrm{~mm}$. in height in 2 years and 9 months, after having been brought from far out on Waikiki reef to within 50 feet of the shore. The rate of growth was obviously not retarded to any great extent by the change of habitat.

A typical effect on coral growth of external attacks of algae is illustrated in Plate IV, $F$, which shows a colony that made no gain in height in a year due to a zone of algae that invaded the apical ridge. Species of Porites and other compact forms are especially subject on Waikiki reef to the smothering effects of a brown alga, Padina sp. (See Pl. V, A.)

Boring algae also affect the life of coral colonies. Duerden (4) has shown them to be filamentous forms that invade the corallum, weakening it, if having no other effect. In broken sections the presence of the algae is detected by a greenish tint just beneath the growing surface or throughout. ( See Pl. V, C.)

The evidence is not conclusive, however, that algae invading the skeletal material check the metabolism of living corals. Some colonies externally free from algae make little growth through long periods. Most of these have their coralla permeated by boring algae, but others as heavily infested have shown good gains in height and weight.

For many corals a measurable amount of basal expansion accompanies vertical growth. A colony $(\mathrm{Pl} . \mathrm{V}, B)$ added $4800 \mathrm{c} . \mathrm{mm}$. in basal extension supplementing an increase in height of $8 \mathrm{~mm}$.

The evidence seems to show that a number of species grow at a more rapid rate on the shores of windward Oahu than on Waikiki reef. Of 2 specimens of Porites lobata forma infundibulum at Kaaawa, one originally weighing 194.8 grams added 191.6 grams in 241 days, whereas on Waikiki reef one of 2 colonies weighing 178.6 grams gained but 97.8 grams in 313 days. The other Kaaawa specimen, weighing 305.6 grams, increased 388.5 grams in 738 days, or an average annual gain of 62.8 per cent. The other Waikiki specimen made a proportionate gain of 45.8 per cent.

A typical example of Porites lobata forma lacera gained $10 \mathrm{~mm}$. in height in one year. (See Table 4.) This species increased in weight less rapidly than either Porites lobata forma infundibulum or Porites evermanni. (See Tables 5 and 6.) 
TABLE 6. INCREASE IN WEIGHT OF FORMS OF PORI'TES LOBATA.

\begin{tabular}{|c|c|c|c|c|c|c|}
\hline & Locality & $\begin{array}{c}\text { Period of } \\
\text { growth } \\
\text { (days) }\end{array}$ & $\begin{array}{l}\text { Average } \\
\text { increase } \\
\text { for period } \\
\text { (grams) }\end{array}$ & $\begin{array}{l}\text { Average } \\
\text { annual } \\
\text { increase } \\
\text { (grams) }\end{array}$ & $\begin{array}{l}\text { Average } \\
\text { annual } \\
\text { increase } \\
\text { (per cent) }\end{array}$ & $\begin{array}{l}\text { Number } \\
\text { of } \\
\text { specimens }\end{array}$ \\
\hline \multirow{2}{*}{$\begin{array}{l}\text { Porites lobata } \\
\text { forma } \\
\text { infundibulum }\end{array}$} & $\begin{array}{c}\text { Waikiki } \\
\text { reef }\end{array}$ & 313 & 52.4 & 62.9 & 56.4 & 2 \\
\hline & $\begin{array}{c}\text { Kaaawa } \\
\text { reef }\end{array}$ & 738 & 326.1 & 162.6 & 64.9 & 2 \\
\hline $\begin{array}{l}\text { Porites lobata } \\
\text { forma lacera }\end{array}$ & $\begin{array}{l}\text { Waikiki } \\
\text { reef }\end{array}$ & $\begin{array}{l}313 \\
305 \\
100\end{array}$ & $\begin{array}{r}48.8 \\
13.0 \\
4.9\end{array}$ & $\begin{array}{l}58.5 \\
15.5 \\
17.9\end{array}$ & $\begin{array}{l}46.7 \\
36.5 \\
32.1\end{array}$ & $\begin{array}{l}2 \\
2 \\
1\end{array}$ \\
\hline \multirow{2}{*}{$\begin{array}{l}\text { Porites lobata } \\
\text { forma centralis } \\
\text { subforma alpha }\end{array}$} & $\begin{array}{l}\text { Waikiki } \\
\text { reef }\end{array}$ & 967 & 1325.7 & 500.4 & 31.7 & 1 \\
\hline & $\begin{array}{c}\text { Kawela } \\
\text { Bay }\end{array}$ & 741 & 197.0 & 97.0 & 38.2 & 2 \\
\hline \multirow{2}{*}{$\begin{array}{l}\text { Porites lobata } \\
\text { forma centralis } \\
\text { subforma beta }\end{array}$} & $\begin{array}{l}\text { Waikiki } \\
\text { reef }\end{array}$ & 532 & 101.1 & 69.4 & 165.5 & 2 \\
\hline & $\begin{array}{c}\text { Kawela } \\
\text { Bay }\end{array}$ & 741 & 129.6 & 63.8 & 81.6 & 1 \\
\hline
\end{tabular}

Average annual increase of forma infundibulum is 60.7 per cent, based on 4 specimens; of forma lacera, 38.4 per cent, based on 5 specimens; of forma centralis subforma alpha, 34.9 per cent, based on 3 specimens; and of forma centralis subforma beta, 123.6 per cent, based on 3 specimens.

A common variety on the reefs of Oahu is Porites lobata forma centralis subforma alpha (Pl. I, $C$ ), which grows in an incrusting manner and has a lumpy surface. One typical specimen made a conspicuous but indeterminate lateral growth in a year, in addition to a gain in height of $5.2 \mathrm{~mm}$. (See Table 4.) A detached colony on Waikiki reef originally weighing 1584.1 grams was re-weighed 5 times at intervals during 967 days. A very consistent gain was shown, the annual average of 31.7 per cent being slightly less than that for 2 specimens in Kawela Bay. (See Table 6.)

Another variety, Porites lobata forma centralis subforma beta (Pl. I, D), made the greatest proportionate gain in weight of any compact form, although it does not attain a large size. (See Table 6.)

The average annual increase in weight of the 3 larger massive corals in Hawaii, Porites evermanni, P. lobata forma infundibulum and forma lacera, based on 19 specimens, is 54.6 per cent, or about 20 per cent greater than Finckh's estimate for one large colony of Porites limora at Funafuti. (See p. 18.)

Additions in height and weight of two varieties of Porites compressa were obtained. (Tables 7 and 8.) Both are common about Oahu and contribute considerable material to the reefs. 
TABLE 7. VERTICAL GROWTH OF FORMS OF PORITES COMPRESSA AT WAIKIKI REEF.

$\begin{array}{ccccc} & \begin{array}{c}\text { Period of } \\ \text { growth (days) }\end{array} & \begin{array}{c}\text { Average increase } \\ \text { for period } \\ \text { (millimeters) }\end{array} & \begin{array}{c}\text { Average annual } \\ \text { increase } \\ \text { (millimeters) }\end{array} & \begin{array}{c}\text { Number of } \\ \text { specimens }\end{array} \\ \begin{array}{c}\text { Porites compressa forma } \\ \text { granimurata }\end{array} & 392 & 14.0 & 13.0 & 1 \\ & 421 & 8.9 & 7.7 & 1 \\ & 369 & 5.9 & 5.8 & 4 \\ & 193 & 1.8 & 3.4 & 12 \\ & 138 & 4.2 & 11.1 & 1 \\ \text { Porites compressa forma } & 145 & 7.0 & 17.6 & 1 \\ \text { angustisepta } & 164 & 5.4 & 12.0 & 1 \\ & 271 & 5.8 & 7.8 & 8 \\ & 231 & 3.9 & 6.2 & 2 \\ & 369 & 8.3 & 8.2 & 4\end{array}$

Average annual increase of forma granimurata is $10.8 \mathrm{~mm}$., based on 21 specimens; of forma angustisepta $7.3 \mathrm{~mm}$., based on 14 specimens.

TABLE 8. INCREASE IN WEIGHT OF FORMS OF PORITES COMPRESSA.

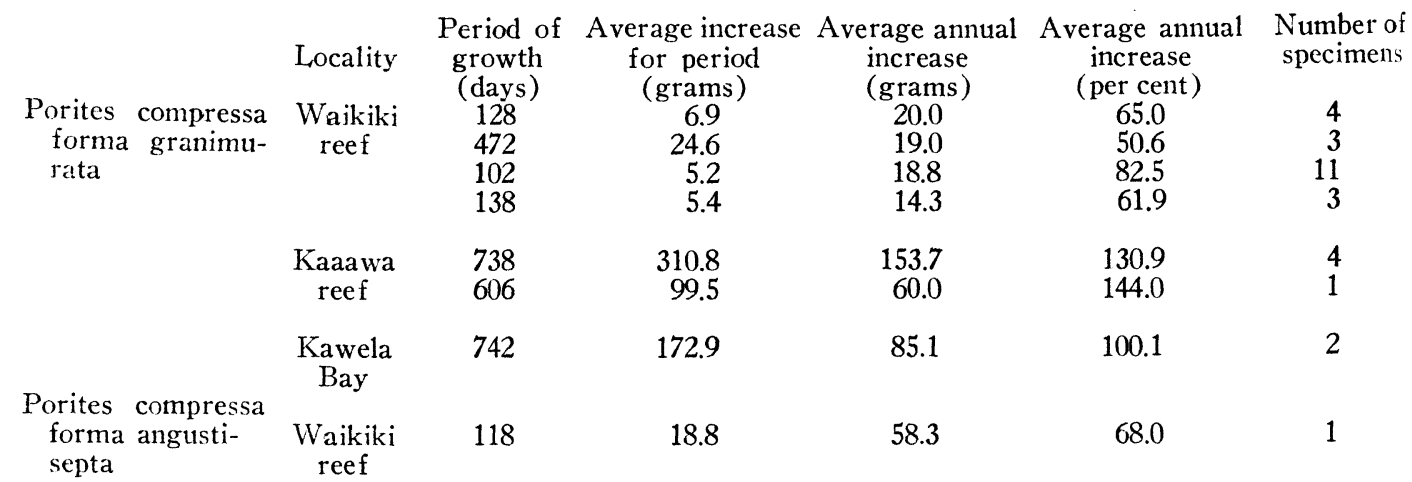

Average annual increase of forma granimurata is 90.7 per cent, based on 28 specimens.

The variety Porites compressa forma angustiscpta (P1. I, E) develops short, blunt lobes having a tendency to be contorted, making precise measurements difficult. A colony gained in height $9.6 \mathrm{~mm}$. in a year. The species may throw out basal expansions equalling, in material deposited, additions to the rest of the colony. The other variety, Porites compressa forma granimurata (Plate I, $F$ ) grows as slender, finger-like lobes, curved and angular. A young specimen gained $14 \mathrm{~mm}$. in height in one year, which was greater than the average for 21 specimens. (See Table 7.) As each lobe of a branching colony may add to its diameter, an increase in skeletal material may be more fully appreciated by weight than by height.

Colonies of Porites compressa forma granimurata on windward Oahu increased in weight at a more rapid rate than specimens on Waikiki reef. 
(See Table 8.) Seven specimens at Kaaawa and Kawela Bay made an average annual gain of 125 per cent, compared with 65 per cent for 21 specimens on Waikiki reef. At Kaaawa a colony weighing 106.6 grams added 209.5 grams during the first 606 days and made a greater proportionate gain of 80.5 grams during the last 132 days. The increase for $73^{8}$ days was 272 per cent.

Among the most conspicuous shallow-water corals of Hawaii are three species of Pocillopora. (See Plate II, $A-C$.) There are few records, however, by means of which a comparison of the rate of growth of species of Pocillopora in Hawaii and other localities in the Pacific Ocean may be made. Finckh (8) reports a colony of Pocillopora grandis in Funafuti as expanding 1 inch in 13.5 weeks, which represents a vertical growth of about 50 $\mathrm{mm}$. a year. Mayor (12) considered the average annual gain in height for species of Pocillopora in Samoa to be $23 \mathrm{~mm}$.

In Hawaii the estimated average yearly increase in height of 3 species of Pocillopora, based on 131 specimens, is $14.4 \mathrm{~mm}$. If the two species forming the larger colonies, $P$. meandrina var. nobilis and $P$. ligulata, are considered, the average annual gain in height is $14.6 \mathrm{~mm}$., based on 125 specimens. A comparison of Tables 9-12 shows that $P$. meandrina var. nobilis gains in height and weight more rapidly than the other species of the genus. The average annual increase of this species in weight, 148 per cent (Table 11), is approximately that reported by Finckh (8) for Pocillopora verrucosa at Funafuti.

TABLE 9. VERTICAL INCREASE OF POCILLOPORA MEANDRINA VAR. NOBILIS A'T WAIKIKI REEF.

$\begin{array}{cccc}\begin{array}{c}\text { Period of } \\ \text { growth } \\ \text { (days) }\end{array} & \begin{array}{c}\text { Average increase } \\ \text { for period } \\ \text { (millimeters) }\end{array} & \begin{array}{c}\text { Average annual } \\ \text { increase } \\ \text { (millimeters) }\end{array} & \begin{array}{c}\text { Number of } \\ \text { specimens }\end{array} \\ 273 & 8.9 & 11.9 & 6 \\ 375 & 3.5 & 4.7 & 4 \\ 370 & 8.2 & 7.9 & 2 \\ 759 & 1.7 & 1.7 & 7 \\ 227 & 8.0 & 3.8 & 1 \\ 231 & 7.0 & 11.2 & 3 \\ 280 & 7.4 & 11.7 & 1 \\ 369 & 8.1 & 10.6 & 3 \\ 508 & 11.1 & 10.9 & 2 \\ 613 & 36.8 & 26.4 & 2 \\ 473 & 31.6 & 18.8 & 5 \\ 482 & 23.8 & 18.4 & 4 \\ 479 & 21.7 & 16.4 & 2 \\ 131 & 28.4 & 21.6 & 8 \\ 443 & 3.3 & 9.2 & 2 \\ 81 & 7.2 & 5.9 & 2 \\ 71 & 8.0 & 36.0 & 4 \\ 50 & 6.0 & 30.8 & 4 \\ 34 & 1.6 & 11.7 & 4\end{array}$

Average annual vertical growth $14.8 \mathrm{~mm}$., based on 107 specimens. 
TABLE 1O. VERTICAL INCREASE OF POCILLOPORA LIGULATA AND POCILI,OPORA CESPITOSA.

$\begin{array}{cccccc}\text { Locality } & \begin{array}{c}\text { Period of } \\ \text { growth } \\ \text { (days) }\end{array} & \begin{array}{c}\text { Average increase } \\ \text { for period } \\ \text { (millimeters) }\end{array} & \begin{array}{c}\text { Average annual } \\ \text { increase } \\ \text { (millimeters) }\end{array} & \begin{array}{c}\text { Number of } \\ \text { specimens }\end{array} \\ \begin{array}{c}\text { Pocillopora } \\ \text { ligulata }\end{array} & \text { Waikiki } & 273 & 3.5 & 4.7 & 3 \\ & \text { reef } & 369 & 6.3 & 6.2 & 2 \\ & & 529 & 31.4 & 21.6 & 4 \\ & & 445 & 7.8 & 19.6 & 4 \\ & & 443 & 24.0 & 19.1 & 1 \\ & \text { Kawailoa } & 369 & 25.2 & 20.7 & 2 \\ \text { Pocillopora } & \text { reef } & & 9.5 & 9.4 & 2 \\ \text { cespitosa } & \text { Waikiki } & 219 & & & \\ & \text { reef } & 225 & 7.1 & 11.3 & 1 \\ & & 479 & 11.0 & 1.3 & 1 \\ & & 529 & 10.4 & 7.4 & 1 \\ & & 443 & 26.5 & 21.8 & 1 \\ & & 81 & 7.4 & 33.3 & 1\end{array}$

Average annual increase of Pocillopora ligulata is $14.5 \mathrm{~mm}$. , based on 18 specimens; of Pocillopora cespitosa, $13.9 \mathrm{~mm}$., based on 6 specimens.

TABLE 11. INCREASE IN WEIGHT OF POCILLOPORA MEANDRINA VAR. NOBIL,IS.

\begin{tabular}{|c|c|c|c|c|c|}
\hline \multirow{13}{*}{$\begin{array}{l}\text { Locality } \\
\text { Waikiki } \\
\text { reef }\end{array}$} & \multirow{13}{*}{ 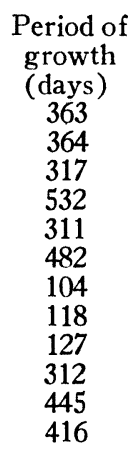 } & \multirow{13}{*}{$\begin{array}{c}\text { Average increase } \\
\text { for period } \\
\text { (grams) } \\
79.4 \\
58.8 \\
53.9 \\
197.9 \\
159.7 \\
29.0 \\
21.9 \\
34.4 \\
11.8 \\
35.4 \\
228.6 \\
147.9\end{array}$} & \multirow{13}{*}{$\begin{array}{c}\text { Average annual } \\
\text { increase } \\
\text { (grams) } \\
79.4 \\
58.8 \\
62.1 \\
135.3 \\
186.9 \\
21.9 \\
76.9 \\
106.3 \\
34.2 \\
41.3 \\
186.9 \\
129.3\end{array}$} & \multirow{13}{*}{$\begin{array}{c}\text { Average annual } \\
\text { increase } \\
\text { (per cent) } \\
234.9 \\
142.6 \\
146.0 \\
86.3 \\
369.5 \\
69.7 \\
167.8 \\
233.0 \\
101.5 \\
38.9 \\
86.9 \\
178.1\end{array}$} & \multirow{13}{*}{$\begin{array}{c}\text { Number of } \\
\text { specimens } \\
4 \\
2 \\
1 \\
1 \\
6 \\
4 \\
1 \\
15 \\
3 \\
8 \\
1 \\
1\end{array}$} \\
\hline & & & & & \\
\hline & & & & & \\
\hline & & & & & \\
\hline & & & & & \\
\hline & & & & & \\
\hline & & & & & \\
\hline & & & & & \\
\hline & & & & & \\
\hline & & & & & \\
\hline & & & & & \\
\hline & & & & & \\
\hline & & & & & \\
\hline K & 742 & & & 140.8 & 3 \\
\hline & 563 & & 281.4 & 75.1 & 1 \\
\hline
\end{tabular}

Average annual increase, 148 per cent, based on 51 specimens.

The possible maximum growth attained by species of Pocillopora in Hawaii is, however, much greater than the estimated averages given by me. One of 2 specimens of $P$. meandrina var. nobilis in 508 days (Table 9) made a vertical gain of $52.5 \mathrm{~mm}$., which represents an annual growth of about $39.6 \mathrm{~mm}$. This colony expanded laterally more than $75 \mathrm{~mm}$. a year. Of 2 specimens observed for 613 days ('Table 9) one increased vertically $36.7 \mathrm{~mm}$., or an annual gain of $21.6 \mathrm{~mm}$., with a lateral expanse of nearly $50 \mathrm{~mm}$. Plate $\mathrm{V}, E$ and $F$, which illustrate the comparative size of this specimen when first and last measured, also indicate a uniform 
expanse of the colony. Other specimens also made remarkable gains through shorter periods. One of 2 colonies in 81 days (Table 9) made a vertical growth of $9.7 \mathrm{~mm}$., which if continued throughout the year would result in an increase of $43.6 \mathrm{~mm}$. and a lateral expanse of more than $8 \mathrm{~cm}$.

I have also recorded some unusual advances in weight for this species. The original average weight of 15 colonies (Table 11) was 54 grams. Of these, one colony of 28 grams added 143.3 grams, making a gain of 511.7 per cent in 311 days. The smallest increase, 168.7 per cent, was shown by a specimen weighing 39.5 grams. Seven of the 15 colonies each added more than 300 per cent in weight in 311 days.

In Kawela Bay, windward Oahu, one of 3 colonies weighing 161.4 grams gained 521.6 grams in 742 days, or 145.5 per cent a year (Table 11).

Some exceptionally rapid increases in both height and weight have been observed among specimens of Pocillopora ligulata. One of 4 colonies in 529 days increased in height $42.1 \mathrm{~mm}$., or $28 \mathrm{~mm}$. annually, whereas each of 2 others of the same lot averaged $25 \mathrm{~mm}$. in vertical growth (Table 10). Two of 5 colonies of this species in Kawela Bay each gained more than 800 per cent in weight during 742 days (Table 12). The specimen making the greatest increase originally weighed 38.2 grams. The other one weighed 136.7 grams. Another specimen in the same locality, weighing 103.5 grams, gained 361 grams in 742 days, making an annual increase of 171.5 per cent.

TABLE 12. INCREASE IN WEIGHT OF POCILLOPORA LIGULATA AND POCILLOPORA CESPITOSA.

\begin{tabular}{|c|c|c|c|c|c|c|}
\hline & Locality & $\begin{array}{l}\text { Period of } \\
\text { growth } \\
\text { (days) }\end{array}$ & $\begin{array}{l}\text { Average increase } \\
\text { for period } \\
\text { (grams) }\end{array}$ & $\begin{array}{l}\text { Average annual } \\
\text { increase } \\
\text { (grams) }\end{array}$ & $\begin{array}{l}\text { Average annual } \\
\text { increase } \\
\text { (per cent) }\end{array}$ & $\begin{array}{l}\text { Number of } \\
\text { specimens }\end{array}$ \\
\hline \multirow[t]{2}{*}{$\begin{array}{c}\text { Pocillopora } \\
\text { ligulata }\end{array}$} & $\begin{array}{l}\text { Waikiki } \\
\text { reef }\end{array}$ & $\begin{array}{l}216 \\
128 \\
104 \\
459 \\
101 \\
100 \\
118 \\
249\end{array}$ & $\begin{array}{r}28.2 \\
58.2 \\
28.0 \\
224.5 \\
25.6 \\
11.9 \\
8.6 \\
24.7\end{array}$ & $\begin{array}{r}47.6 \\
166.0 \\
98.3 \\
178.5 \\
92.6 \\
43.2 \\
26.7 \\
36.3\end{array}$ & $\begin{array}{r}144.1 \\
212.7 \\
244.3 \\
95.5 \\
125.0 \\
89.5 \\
45.5 \\
20.6\end{array}$ & $\begin{array}{l}4 \\
4 \\
8 \\
2 \\
3 \\
3 \\
1 \\
1\end{array}$ \\
\hline & $\begin{array}{c}\text { Kawela } \\
\text { Bay }\end{array}$ & 742 & 523.6 & 257.5 & 260.2 & 5 \\
\hline $\begin{array}{r}\text { Pocillopora } \\
\text { cespitosa }\end{array}$ & $\begin{array}{l}\text { Waikiki } \\
\text { reef }\end{array}$ & $\begin{array}{l}195 \\
154 \\
104 \\
100 \\
118 \\
217\end{array}$ & $\begin{array}{r}24.0 \\
6.1 \\
2.1 \\
10.5 \\
13.5 \\
34.7\end{array}$ & $\begin{array}{r}44.9 \\
14.6 \\
7.3 \\
38.2 \\
41.9 \\
59.0\end{array}$ & $\begin{array}{r}49.9 \\
238.2 \\
53.7 \\
57.5 \\
115.9 \\
108.1\end{array}$ & $\begin{array}{l}1 \\
3 \\
1 \\
2 \\
3 \\
2\end{array}$ \\
\hline
\end{tabular}

Average anmual increase of Pocillopora ligulata is 137.5 per cent, based on 31 specimens; of Pocillopora cespitosa, 103.9 per cent, based on 12 specimens. 
Colonies of Pocillopora cospitosa (P1. II, C) do not attain the size reached by other Hawaiian species of the genus. Specimens of this coral 6 inches in diameter are considered exceptionally large. The vertical increase made by one specimen in 443 days, with an estimated annual gain of $21.8 \mathrm{~mm}$., makes possible the full growth of the species in 6 or 7 years. An exceptional gain of $7.4 \mathrm{~mm}$. was made by one specimen in 81 days (Table 10 ). The estimated annual increase of $33.3 \mathrm{~mm}$., based on the growth for 81 clays, is, however, probably excessive, as it is unlikely this rate would continue throughout the year. Gains in weight by this species indicate that comparatively small colonies make the best showing. The 3 specimens observed for 154 days averaged less than 6 grams when first weighed, but made an estimated annual gain of 238.2 per cent, whereas one of two colonies weighing 100.6 grams showed a yearly gain of but 44.1 per cent (Table 12).

Although specimens of Pocillopora may, occasionally, grow rapidly, the larger number of specimens measured showed a vertical increase of considerably less than $25 \mathrm{~mm}$. a year. Of 131 colonies, including 3 species, 84 made an annual gain of less than $12 \mathrm{~mm}$., and of 107 colonies of P. meandrina var. nobilis, 26 increased in height less than $5 \mathrm{~mm}$. annually. Vertical gains of $26.5 \mathrm{~mm}$. in 613 days and of $10.4 \mathrm{~mm}$. and $18.6 \mathrm{~mm}$. per year, made by young colonies on Waikiki reef, are typical of the greater number of specimens I have examined. The greatest gain in weight I have observed for this species, based on one year's growth, is 600.5 per cent; the smallest, 26.2 per cent; each colony originally weighing between 20 and 30 grams.

Although species of Pocillopora are comparatively short-lived and under most favorable conditions in Hawaii colonies do not attain much over $30 \mathrm{~cm}$. in diameter, the large number of specimens would indicate that the genus is a factor of some importance in contributing skeletal material to the reef.

Species of Porites and Pocillopora have probably always been the leading contributors among corals to reef formation in Hawaii. Other genera include species of less consequence. The value they may have rests in the number of colonies produced rather than in the size attained or the rapiclity of growth.

The species Cyphastrea occllina (Pl. II, $D$ ), very common on the reefs of Oahu, produces irregular masses or incrustations seldom more than 6 or $8 \mathrm{~cm}$. in diameter. It makes slow growth when young (p. 11) and also during older stages. (See Tables 13 and 14.) A typical colony, free from algae, growing into a rounded lump, added $1.5 \mathrm{~mm}$. in height in 271 days, or at the rate of about $2 \mathrm{~mm}$. a year. Another colony was marked to determine lateral expansion. A basal extension of $125 \mathrm{sq} . \mathrm{mm}$., averaging $2 \mathrm{~mm}$. in thickness, developed in 370 days. 
Colonies of Stephanaria stellata and Stephanaria brighami, similar in form and size, are numerous on Hawaiian reefs. Records of Stephanaria stellata (Pl. III, $B$ ) only were obtained. Although growth in height varies greatly (Table 13), about $8 \mathrm{~mm}$. a year may be considered a maximum. A specimen weighing 16.9 grams added 4.1 grams in 128 days, or an estimated annual gain of 69.8 per cent, whereas another weighing 88.4 grams gained but 27.1 per cent. The average growth of these two colonies is given in Table 14.

TABLE 13. VERTICAL INCREASE OF SPECIES OF CYPHASTREA, MONTIPORA, AND STEPHANARIA, AT WAIKIKI REEF.

$\begin{array}{lcccc}\text { Cyphastrea ocellina } & \begin{array}{c}\text { Period of } \\ \text { growth } \\ \text { (days) } \\ 271\end{array} & \begin{array}{c}\text { Average increase } \\ \text { for period } \\ \text { (millimeters) } \\ \text { B. }\end{array} & \begin{array}{c}\text { Average annual } \\ \text { increase } \\ \text { Basal expansion } \\ \text { of } 250 \text { c. mm. }\end{array} & \begin{array}{c}\text { Number of } \\ \text { specimens }\end{array} \\ \text { Montipora verrucosa } & 369 & 14.0 & 14.0 & 1 \\ \text { Stephanaria stellata } & 271 & 1.4 & 1.8 & 1 \\ & 280 & 7.8 & 10.1 & 3 \\ & 369 & 8.2 & 8.1 & 1 \\ & 267 & 5.4 & 7.0 & 3 \\ & 89 & 0.4 & 1.6 & 1\end{array}$

Average annual increase of Stephanaria stellata is $5.7 \mathrm{~mm}$., based on 10 specimens.

TABLE 14. INCREASE IN WEIGHT OF SPECIES OF CYPHASTREA, MONTIPORA, STEPHANARIA, AND PAYONA, AT WAIKIKI REEF.

\begin{tabular}{|c|c|c|c|c|c|}
\hline $\begin{array}{c}\text { Cyphastrea } \\
\text { ocellina }\end{array}$ & $\begin{array}{l}\text { Period of } \\
\text { growth } \\
\text { (days) } \\
100\end{array}$ & $\begin{array}{c}\text { Average increase } \\
\text { for period } \\
\text { (grams) } \\
4.5\end{array}$ & $\begin{array}{c}\text { Average annual } \\
\text { increase } \\
\text { (grams) } \\
16.7\end{array}$ & $\begin{array}{l}\text { Average annual } \\
\text { increase } \\
\text { (per cent) } \\
22.2\end{array}$ & $\begin{array}{c}\text { Number of } \\
\text { specimens } \\
1\end{array}$ \\
\hline $\begin{array}{l}\text { Montipora } \\
\text { verrucosa }\end{array}$ & $\begin{array}{l}302 \\
128 \\
101\end{array}$ & $\begin{array}{r}11.9 \\
5.1 \\
7.0\end{array}$ & $\begin{array}{l}14.3 \\
14.6 \\
25.3\end{array}$ & $\begin{array}{l}61.4 \\
14.8 \\
78.4\end{array}$ & $\begin{array}{l}1 \\
2 \\
5\end{array}$ \\
\hline $\begin{array}{l}\text { Stephanaria } \\
\text { stellata }\end{array}$ & 128 & 6.3 & 17.9 & 48.5 & 2 \\
\hline $\begin{array}{l}\text { Pavona } \\
\text { varians }\end{array}$ & 101 & 6.2 & 22.3 & 40.0 & 2 \\
\hline
\end{tabular}
mens.

Average annual increase of Montipora verrucosa is 51.5 per cent, based on 8 speci-

Due to the mode of growth of Montipora verrucosa (Pl. II, E) exact vertical measurements of the colony as a whole are impossible. Lobes or irregularities of the surface of one specimen developed at the rate of about $14 \mathrm{~mm}$. a year. (See Table 13.) The species may gain rapidly in weight, as is shown by Table 14 . One specimen weighing 30.1 grams, in 101 days 
increased at the rate of 111.7 per cent a year. Another colony, however, weighing 102.8 grams, gained in 128 days at the rate of but 17.9 per cent a year.

As the growth of Pavona varians (Pl. III, C) is chiefly in a lateral direction, spreading over irregular contours of supporting surfaces, only gains in weight were recorded. Two colonies weighing 68.6 grams and 44.7 grams added 10.1 per cent and 12.1 per cent, respectively, in 101 days. The estimated annual gain for the species is about 40 per cent. (See Table 14.)

In form of growth, Leptastrea purpurea and L. agassizi are similar, both incrusting fixed, irregular surfaces or appearing as detached, nodular specimens. (See Pls. II, F, and III, A.) In Hawaii each species develops small colonies, most of them not more than 10 or $15 \mathrm{~cm}$. across. Their rate of expansion is very slow. Being compact forms, however, a relatively large amount of weight may be gained with slight increase in size.

Table 16 shows the estimated annual gain in weight of 5 selected specimens of Leptastrea purpurea of the nodular form. The colony making the greatest increase originally weighed 90.6 grams, and the one making the least gain weighed 125.5 grams. Two specimens of Leptastrea agassizi making an estimated average increase in length of $2.8 \mathrm{~mm}$. in a year added weight at the rate of 48.8 per cent annually, based on a growth of 154 days. (See Tables 15, 16.) One of the two colonies, weighing 64.6 grams, gained at the rate of 74.9 per cent annually, which was the highest record for the species. The lowest estimated annual increase was 9.2 per cent, made by a specimen weighing 93.7 grams, based on a growth of 159 days.

TABLE 15. INCREASE IN LENGTH OF SPECIES OF LEPTASTREA AND FUNGIA, AT WAIKIKI REEF.

\begin{tabular}{|c|c|c|c|c|}
\hline & $\begin{array}{c}\text { Period of } \\
\text { growth } \\
\text { (days) }\end{array}$ & $\begin{array}{l}\text { Average increase } \\
\text { for period } \\
\text { (millimeters) }\end{array}$ & $\begin{array}{l}\text { Average annual } \\
\text { increase } \\
\text { (millimeters) }\end{array}$ & $\begin{array}{l}\text { Number of } \\
\text { specimens }\end{array}$ \\
\hline Leptastrea agassizi & 154 & 1.2 & 2.8 & 2 \\
\hline $\begin{array}{l}\text { Fungia scutaria var. dentigera; } \\
\text { free specimens }\end{array}$ & $\begin{array}{l}334 \\
368\end{array}$ & $\begin{array}{l}5.3 \\
3.3\end{array}$ & $\begin{array}{l}5.9 \\
3.3\end{array}$ & $\begin{array}{l}2 \\
8\end{array}$ \\
\hline $\begin{array}{l}\text { Fungia scutaria var. dentigera; } \\
\text { attached to old specimens }\end{array}$ & $\begin{array}{l}349 \\
349 \\
349 \\
349 \\
349\end{array}$ & $\begin{array}{l}16.9 \\
15.5 \\
10.7 \\
16.5 \\
19.2\end{array}$ & $\begin{array}{l}17.7 \\
15.9 \\
11.2 \\
17.2 \\
20.0\end{array}$ & $\begin{array}{r}14 \\
4 \\
4 \\
2 \\
4\end{array}$ \\
\hline
\end{tabular}

Average annual increase of free specimens of Fungia scutaria var. dentigera is 4.6 $\mathrm{mm}$., based on 10 specimens; of attached specimens $16.4 \mathrm{~mm}$., based on 28 specimens. 
TABLE 16. INCREASF, IN WEIGHT OF SPFCIES OF LEP'TASTREA AND FUNGIA, AT WAIKIKI REEF.

$\begin{array}{cccccc}\text { Leptastrea } & \begin{array}{c}\text { Period of } \\ \text { growth } \\ \text { (days) }\end{array} & \begin{array}{c}\text { Average increase } \\ \text { for period } \\ \text { (grams) }\end{array} & \begin{array}{c}\text { Average annual } \\ \text { increase } \\ \text { (grams) }\end{array} & \begin{array}{c}\text { Average annual } \\ \text { increase } \\ \text { (per cent) }\end{array} & \begin{array}{c}\text { Number of } \\ \text { specimens }\end{array} \\ & 459 & 20.2 & 16.1 & 7.0 & 1 \\ \text { Leptastrea } & 154 & 2.8 & 6.7 & 5.3 & 1 \\ \text { agassizi } & 159 & 22.0 & 50.6 & 55.7 & 1 \\ & 217 & 8.9 & 15.1 & 18.0 & 1 \\ & 269 & 5.6 & 7.6 & 13.3 & 1 \\ \text { Fungia scutaria } & 313 & 13.6 & 15.8 & 20.6 & 2 \\ \text { var. dentigera } & 159 & 16.5 & 39.1 & 48.8 & 5 \\ & 459 & 4.8 & 11.0 & 15.8 & 1 \\ & 217 & 27.2 & 21.6 & 10.5 & 2 \\ & 313 & 15.8 & 26.5 & 34.4 & 1\end{array}$

Average annual increase of Leptastrea purpurea is 19.9 per cent, based on 5 specimens; of Leptastrea agassizi, 26 per cent, based on 11 specimens; of Fungia scutaria var. dentigera 17.4 per cent, based on 3 specimens.

Young Fungia develop from old colonies as "mushroom-like" buds, which may remain fixed by their stalks for more than a year. (See Pl. V,D.)

Specimens of Fungia increase in size at a slower rate after breaking away from the old colonies than when attached. One of the free specimens under observation for 334 days (Table 15) was $50 \mathrm{~mm}$. in length when first measured, the other $53.8 \mathrm{~mm}$. For the first 282 days an appreciable gain was noted for each specimen, measured at intervals of 3 months, but during the last 52 days no increase in length was made by either. A small but consistent increase in weight was recorded for each specimen during the period of observation.

The greatest individual gain in length of 6 detached specimens of Fungia was at a rate of less than $5 \mathrm{~mm}$. a year. (Table 17.) In this group the smallest increase in length, $1.5 \mathrm{~mm}$., and also the least proportionate gain in weight, 9.7 per cent, were made by the largest specimen. 
TABLE 17. INCREASE IN WEIGHT AND LENGTH OF 6 YOUNG SPECIMENS OF FUNGIA: AFTER BECOMING DE'TACHED. W, WEIGHT IN GRAMS ; L, LENGTH IN MILLIMETERS. TIME, 617 DAYS.

\begin{tabular}{|c|c|c|c|c|c|c|c|c|c|c|c|}
\hline \multicolumn{2}{|c|}{ Oct. 4, '26 } & \multicolumn{2}{|c|}{ Dec. 16, '26 } & \multicolumn{2}{|c|}{ Mar. 4, '27 } & \multicolumn{2}{|c|}{ July $13, ' 27$} & \multicolumn{2}{|c|}{ Oct. 7, '27 } & \multirow{2}{*}{\multicolumn{2}{|c|}{ June $13, ' 28$}} \\
\hline W & $\mathrm{I}$ & W & L, & W & L & W & $\mathrm{L}$ & W & $\mathrm{L}$ & W & \\
\hline 26.3 & 47.6 & 26.3 & 48.4 & 26.3 & 49.2 & 26.3 & 50.0 & 28.3 & 50.0 & 35.9 & \\
\hline 20.2 & 50.0 & 21.5 & 50.8 & 21.7 & 51.5 & 22. & 51.5 & 24 & 52.0 & 31.7 & \\
\hline 47.3 & 58.2 & 47.7 & 58 & 49.0 & 58. & 50 & 58. & 51 & 59 & 5 & \\
\hline 9.9 & 33.6 & 10. & & 10.2 & & 10 & & & 36.3 & 11.5 & \\
\hline 18.9 & 51.5 & 20.3 & 52 & 22.5 & 53. & 24 & 54.7 & 26 & 3 & 29.0 & \\
\hline 4.3 & 26. & 4.3 & 26 & 4.4 & 27 & 4.9 & 27.6 & 5.2 & 28.1 & 6.0 & \\
\hline
\end{tabular}

Average annual increase in weight, 3.8 grams; in length, $2.6 \mathrm{~mm}$., based on 6 specimens.

TABLE 18. INCREASE IN LENGTH OF 14 SPECIMENS OF ATTACHED FUNGIA. MEASUREMENTS IN MILLIMETERS AT INTERVALS DURING 349 DAYS.

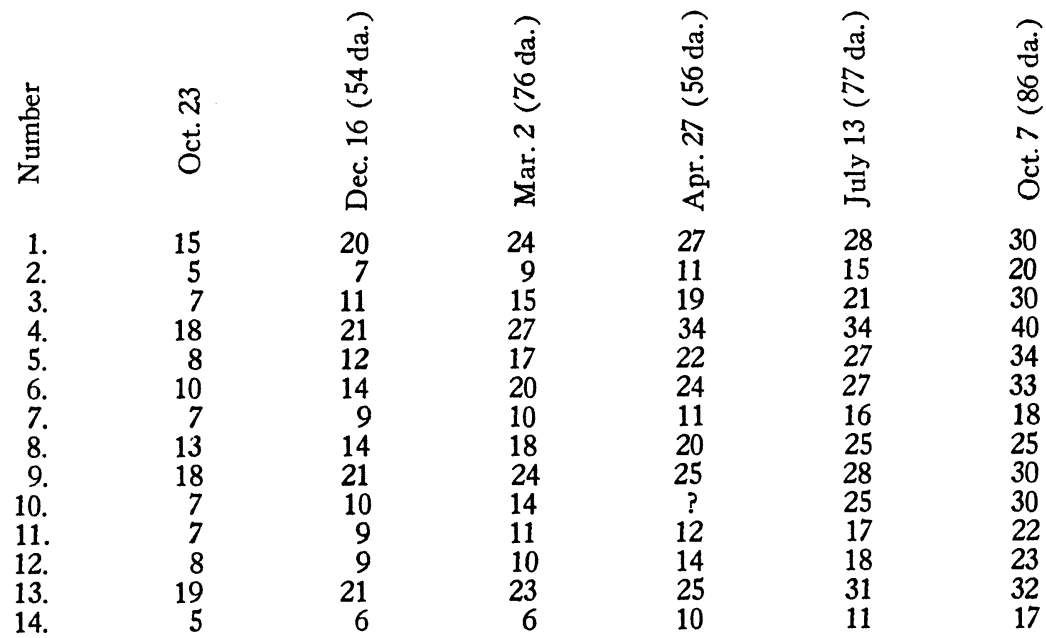

Average annual increase in length, $17.7 \mathrm{~mm}$., based on 14 specimens.

The gains made by 14 attached specimens, as detailed in Table 18 , show not only the erratic growth of different colonies under similar ecological conditions but also the successive states of activity and quiescence exhibited by certain individuals. An average increase in length of $16.9 \mathrm{~mm}$. in 349 days was made by this group.

Specimen No. 5 advanced from $8 \mathrm{~mm}$. to $34 \mathrm{~mm}$., making a consistent gain during the period of observation, but specimen No. 7, which increased from $7 \mathrm{~mm}$. to $18 \mathrm{~mm}$., grew more rapidly in the 77 days, April 27 to July 13, than during the preceding 186 days, and twice as rapidly as during the follow- 
ing 86 days. Specimen No. 4, originally $18 \mathrm{~mm}$. long, increased consistently from October 23 to April 27, but made no gain in the next 77 days, then increased rapidly during the following 86 days. Specimen No. 14 gained but $1 \mathrm{~mm}$. in the first 4 months, but advanced $4 \mathrm{~mm}$. in 56 days, March 2 to April 27, and $6 \mathrm{~mm}$. during the last 86 days.

Table 18 indicates that the greatest average daily gain in length of 14 specimens was made from March 2 to April 27 and the least from December 16 to March 2. Such an observation, however, has little significance when irregularities of growth are so clearly shown in the same or different specimens.

All specimens of Fungia under observation for growth records were enclosed in galvanized wire baskets set in cement blocks (p. 20) and placed on Waikiki reef about 150 feet from the shore. This locality was probably not an optimum one for the species, being nearer the shore and in more shallow water than usual. For this reason the increases in growth shown may be slightly subnormal.

Experiments were carried on with Leptastrea purpurea and Fungia scutaria to determine the amount of weight lost when subjected to abnormal conditions, without artificial feeding. A specimen of Leptastrea weighing 120.48 grams was placed in dilute sea water, represented by 4 parts of sea water to 1 part of fresh water, with the solution changed daily. At the end of 4 months a loss of 1.54 grams was recorded.

On exposing a specimen of Fungia, weighing 225.15 grams, to a solution of 3 parts of sea water to 1 part of fresh water, changed daily, for 10 months, a loss of 58.60 grams was indicated. During the first month the loss was 47.16 grams.

In sea water reduced in hydrogen ion concentration from $\mathrm{pH} 8.5$ to $\mathrm{pH} 7.0$ a specimen of Fungia weighing 192.76 grams lost 20.36 grams in 6 months. A reduction of 12.77 grams occurred during the first 30 days. Another specimen weighing 134.41 grams lost but 3.3 grams in 6 months in neutral sea water.

All specimens exposed to dilute or neutral sea water, without artificial feeding, were alive at the terminations of the experiments, but the effects of the unusual treatment were obvious. In most a rapid loss of weight occurred during the first month, after which an adjustment obviously took place, metabolism probably slowing up with the lack of nourishment.

On being subjected to filtered, circulating sea water for 3 months, Leptastrea purpurea completely lost the soft coenenchyma, only the polyps remaining alive. An apparent auto-digestion occurred with the approach of inanition, the coenenchyma growing thin and disappearing first at points farthest from the polyps. 
That Anthozoa may derive nutriment from zooxanthellae infesting their tissues has gained support through the recent investigations of Boschma (1). It would seem, however, that prolonged fasting may bring about not only digestion of the algal cells but of the coral tissue itself.

On being restored to normal sea water the starved specimen of Leptastrea regenerated the coenenchyma in 4 months.

The difference in weight between the living coral colony and the dried skeleton represents the weight of the living tissue plus adhering water. An attempt was made to estimate the relative proportion of living tissue and skeletal material in order to approximate the amount of limestone deposited by a colony in a given period of time.

Colonies free from foreign material were selected and weighed, after being thoroughly shaken to remove as much adhering water as possible. The specimens were then killed, the living organic matter removed, and the skeleton dried and reweighed. In 20 selected colonies of Pocillopora meandrina var. nobilis the organic matter and adhering water averaged 16.2 per cent of the total weight of the original colony. In 50 colonies of Pocillopora ligulata the average was 11.8 per cent. Twenty-eight colonies of Porites compressa forma granimurata showed an average of 15 per cent, and in 14 colonies of Montipora verrucosa, a very porous form, the average was 30.1 per cent. One colony of Leptastrea agassizi showed a difference of $9.1 \mathrm{per}$ cent.

To arrive at some estimate of the amount of water still adhering to a colony when weighed, after most of it had been shaken off, specimens were weighed before and after being subjected to the air, in the shade or sun, the difference in weight representing the amount of water evaporated during that time. Two species were tested in this manner. It was found that 30 minutes in the shade evaporated approximately as much water as 15 minutes in the sun, and 1 hour in the shade as much as 30 minutes in the sun.

In a previous paper (7) I showed that Pocillopora meandrina var. nobilis and Pocillopora ligulata, while out of water, endure the direct rays of the sun for more than 30 minutes. In the present experiment, on exposing Pocillopora meandrina var. nobilis to the sun for 30 minutes it was found that the amount of water evaporated from 12 specimens averaged 2.6 per cent of the original weight of the colonies. In 10 colonies of Pocillopora ligulata the average was 3.5 per cent after an exposure of 1 hour in the shade.

It is safe to say that from 2 per cent to 5 per cent of water adheres to a colony after being thoroughly shaken. In estimating the increase in weight of coral colonies, therefore, approximately 10 per cent may consist of the soft parts, 5 per cent of adhering water, and 85 per cent of skeletal material. 


\section{SUMMARY AND CONCLUSIONS}

Planulae of different species of corals exhibit distinct characteristics in morphology and behavior. Their resistance to many abnormal conditions is greater than that of the adults of the same species.

Planulae settle and become affixed under a wide range of conditions. Affixation of planulae in clusters frequently occurs in the laboratory.

Subsequent to affixation of planulae, polyps of different species vary in the rate of their early development. Pocillopora cespitosa develops rapidly, Cyphastrea ocellina slowly.

Corals in Hawaii are poorly developed on the upper surface of the reef, but show much greater activity on the outer rim, at depths from 2 to 4 fathoms.

On the surface of the reef in Hawaii corals increase in height less rapidly than in the Indian and South Pacific oceans. The rate of growth in Hawaii corresponds more nearly to that recorded in the Bahamas and Dry Tortugas.

Massive forms of Porites in Hawaii gain in height 8 to $10 \mathrm{~mm}$. and in weight about 60 per cent annually. Branching forms of Porites increase in height at about the same rate as massive ones and, on an average, gain about 80 per cent in weight annually.

Species of Pocillopora in Hawaii make an average annual increase of about $15 \mathrm{~mm}$. in height and more than 100 per cent in weight. Some colonies of Pocillopora meandrina var. nobilis have gained in height at the rate of about $40 \mathrm{~mm}$. per year.

Cyphastrea ocellina gains in height about $2 \mathrm{~mm}$. and 22 per cent in weight annually. Surface lobes of Montipora verrucosa may increase in height 14 $\mathrm{mm}$. annually. The average annual gain in weight for 8 specimens was 51.5 per cent. Stephanaria stellata has gained in height at the rate of about 10 $\mathrm{mm}$. annually, but the average is nearer $5 \mathrm{~mm}$. Its annual increase in weight is about 48 per cent. Pavona varians adds weight at the rate of about 40 per cent annually.

Free specimens of Fungia may gain from 5 to $6 \mathrm{~mm}$. in length annually. Young specimens grow from 4 to 6 times more rapidly when attached to old individuals than after becoming free.

Approximately 85 per cent of the total increase in weight of a coral colony represents skeletal material. 


\section{LITERATURE CITED}

1. Boschma, H., The nature of the association between Anthozoa and Zooxanthellae: Nat. Acad. Sci., Proc., vol. 11, no. 1, pp. 65-67, 1925.

2. DUERDEN, J. E., The Edwardsia-stage of the actinian Lebrunia and the formation of the gastro-coelomic cavity: Linn. Soc. London, Jour., vol. 27, Zool., pp. 269316,1899 .

3. DuERDEN, J. E., The coral Siderastrea radians and its postlarval development: Carnegie Inst. Washington, Pub. 20, pp. 1-130, 1904.

4. DuERDEN, J. E., Recent results on the morphology and development of coral polyps: Smithsonian Misc. Coll., vol. 47, pp. 93-111, 1905.

5. Dana, J. D., Corals and coral islands, New York, 1872.

6. Darwin, Charles, On the structure and distribution of coral reefs, London, 1842.

7. Edmondson, C. H., The ecology of an Hawaiian coral reef: B. P. Bishop Mus., Bull. $45,1928$.

8. FincKh, A. E., The atoll of Funafuti : biology of the reef-forming organisms at Funafuti atoll : Royal Soc. London, Report of Coral Reef Comm., sec. 6, pp. 125150,1904 .

9. Guppy, H. B., The Cocos-Keeling islands: Scottish Geographic Mag., vol. 5, no. 6, pp. $281-297$; no. 9 , pp. $457-474$; no. 11 , pp. $569-588,1889$.

10. GARDiner, J. S., Fauna and geography of the Maldive and Laccadive archipelagoes: the rate of growth of corals and reefs, vol. 1, pp. 327-333, 1903.

11. MacMunn, C. A., Fauna and geography of the Maldive and Laccadive archipelagoes: on the pigments of certain corals, vol. 1, pp. 184-190, 1903.

12. MayoR, A. G., Growth rate of Samoan corals: Carnegie Inst. Washington, Pub. 340, pp. 51-72, 1924.

13. McMurrich, J. P., Contributions on the morphology of the Actinozoa, II : on the development of the Hexactiniae: Jour. Morphology, vol. 4, p. 317, pl. 13, flg. 13, 1891.

14. Vaughan, T. W., Recent madreporaria of the Hawaiian islands and Laysan: U. S. Nat. Mus., Bull. 59, 1907.

15. Vaughan, T. W., Growth rate of the Floridian and Bahaman shoal-water corals: Carnegie Inst. Washington, Year Book 14, pp. 221-231, 1915.

16. Vaughan, T. W., Corals and the formation of coral reefs: Smithsonian Rept. for 1917, pp. 189-276, 1919.

17. WOOD-JONES, FREDERICK, Corals and atolls, London, 1910. 


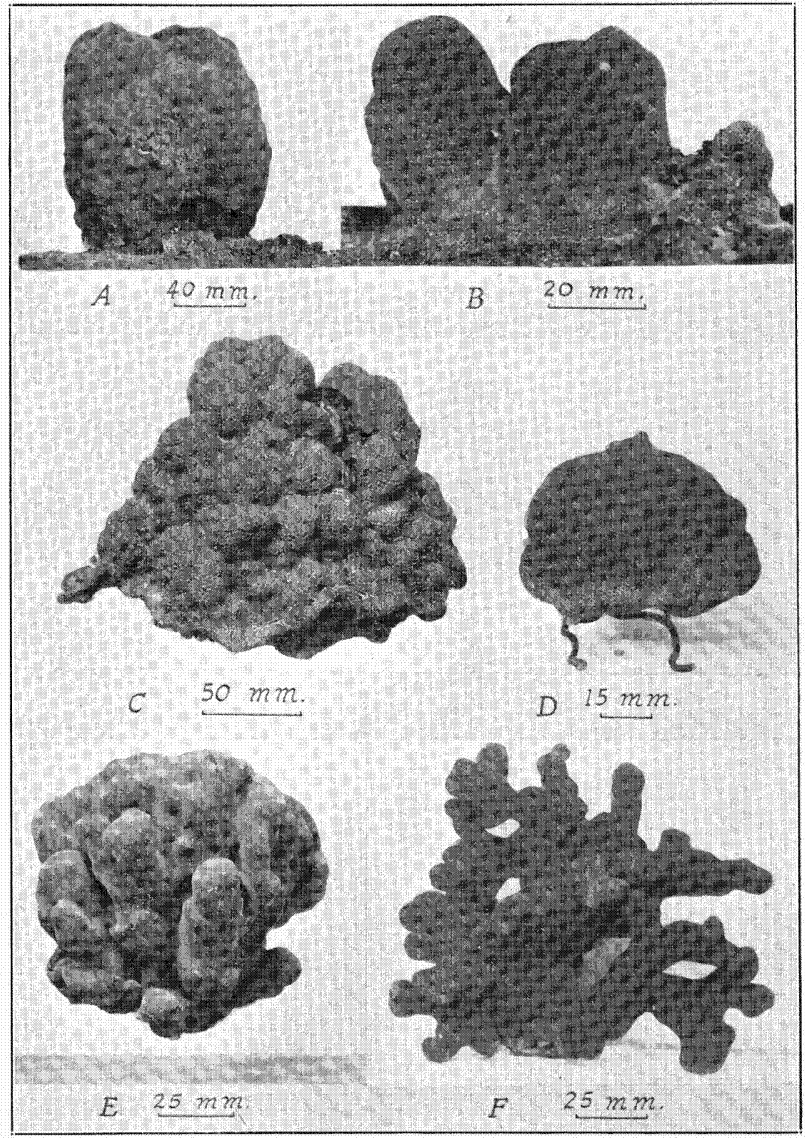

A, PORITES LOBATA FORMA INFUNDTBULUM; $B$, PORTTES LOHATA FORMA LACERA: C. PORITES LOBATA FORMA CENTRALIS SUBFORMA ALPHA; $D$, PORITES LOBATA FORMA CENTRAI,IS SUBFORMA BETA; $E$, PORITES COMPRESSA FORMA ANGUSTISEPTA; $F$, PORITES COMPRESSA FORMA GRANIMURATA. 


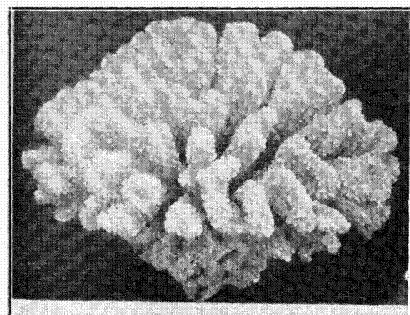

A $20 \mathrm{~mm}$.
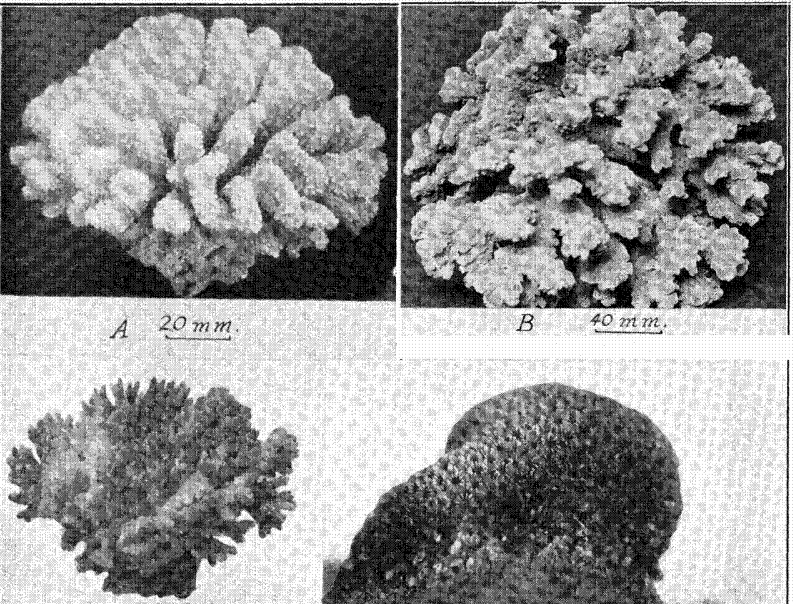

C. $15 \mathrm{~mm}$
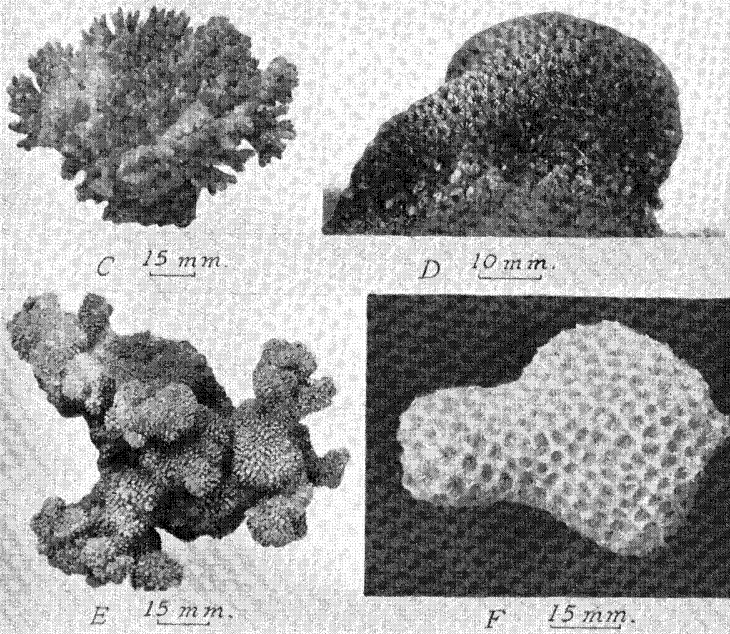

\section{D $10 \mathrm{~mm}$}

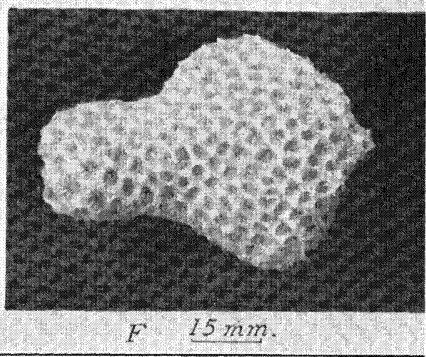

A, POCHLOPORA MEANDRINA VAR. NOBILIS; B, POCILLOPORA LIGULATA; $C$ POCII LOPORA CESPITOSA; $D$, CYPHASTREA OCELLINA; $E$, MONTTPORA VERRUCOSA; $F$, LEPTASTREA PURPUREA. 

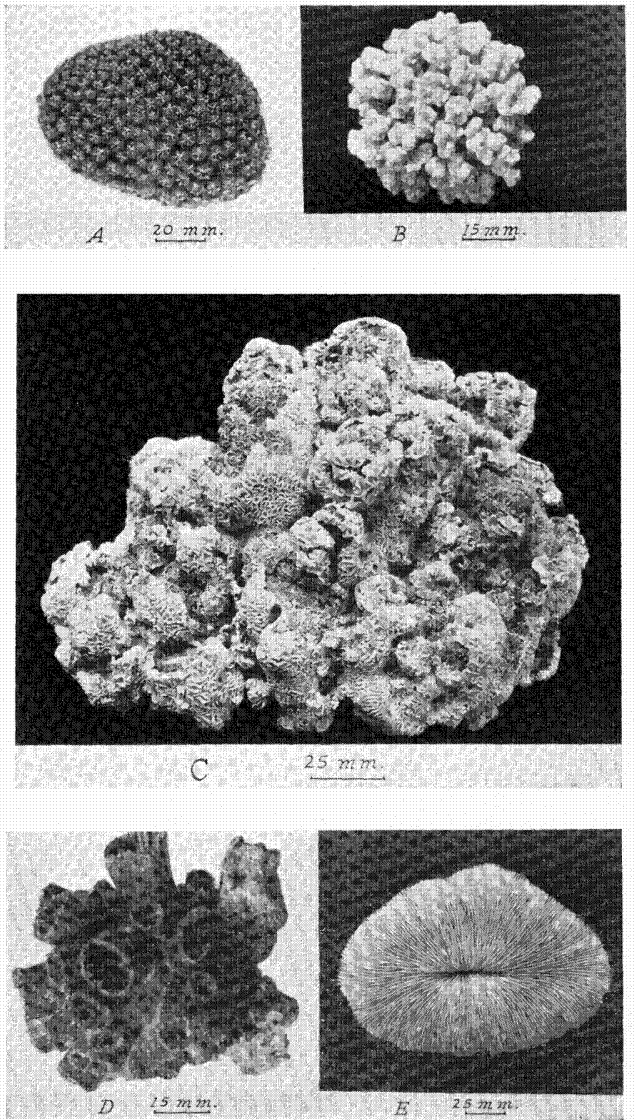

$A$, LEPTASTREA AGASSIZI; $B$, STIPUANARTA STRLIATA; C, PAVONA YARIANS; D, DENDROPHYLLIA MANNI; $E$, FUNGIA SCU'TARIA VAR, DENTIGTRA. 


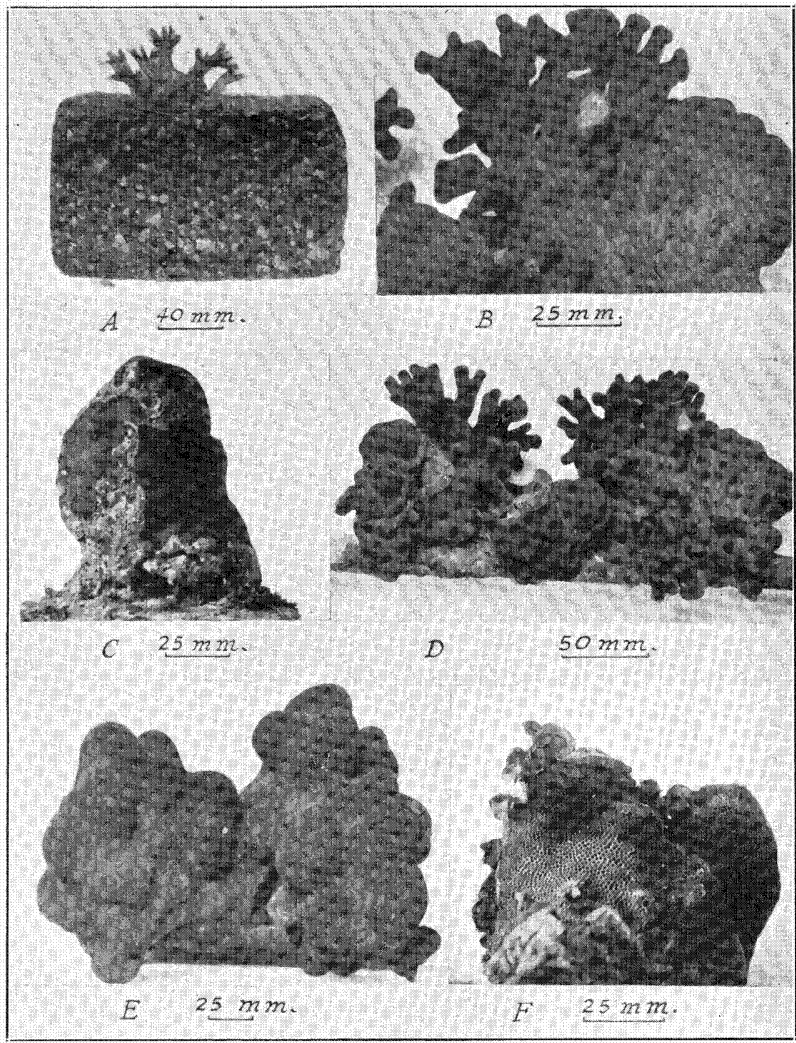

A, A COLONY OF POCIILOPORA CESPITOSA 6. MONTHS OLD, GROWN FROM THE PI,AN. ULA; $B$, TWO SPECIES, PORITES COMPRESSA FORMA CRANIMURATA AND PORITES EVERMANNI, UNITED BY A CURVED, COMPRESSED RIDCE, WITH NO FUSION OF CALICLES: C, A SPECIMEN OF PORITES LOBATA FORMA INFUNDIBUI,UM PARTIALI, D DESTROYED BY ALGAE, WHICH ARE ADVANCING FROM THE BASE OVER THE SURFACE OF THE CORAL, COLONY: $D$, FIVE COIONIES UNITED, PORITES EVERMANNI ALTERNATING WITH PORITES COMPRESSA FORMA GRANIMURATA; E, TWO COLONIES OF PORITES EVERMANNI UNITED. PERFECT FUSION OF CAITCLIS AT THE CONTACT SHOWN BY THE DIAGONAL LINE; $F$, A SPECIMEN OF PORITES I.OBTA FORMA INFUNDHULLUM WHICH MADE NO GAIN IN HEIGHT IN A YEAR DUE TO A GROWTH OF ALGAE OVER THE CROWN OF THE CORAL, COL.ONY. 

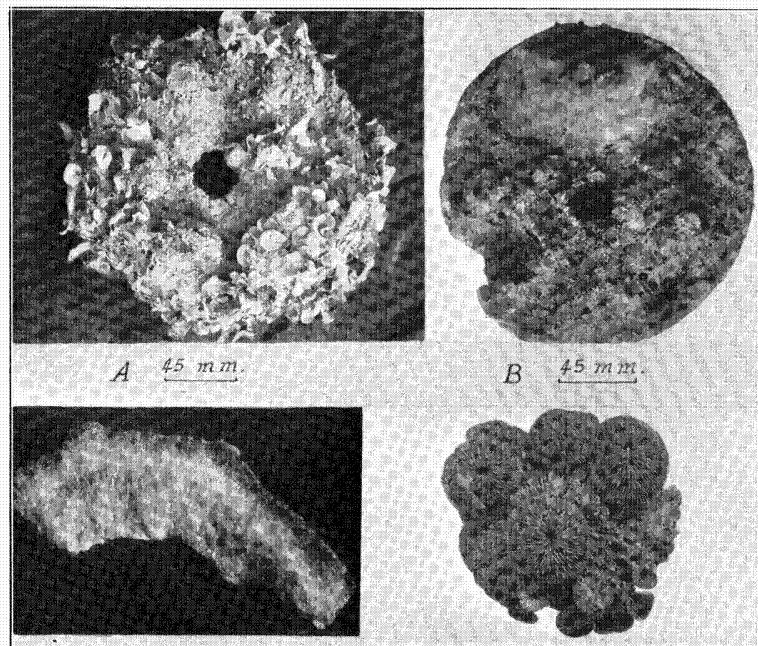

C. $20 \mathrm{~mm}$.
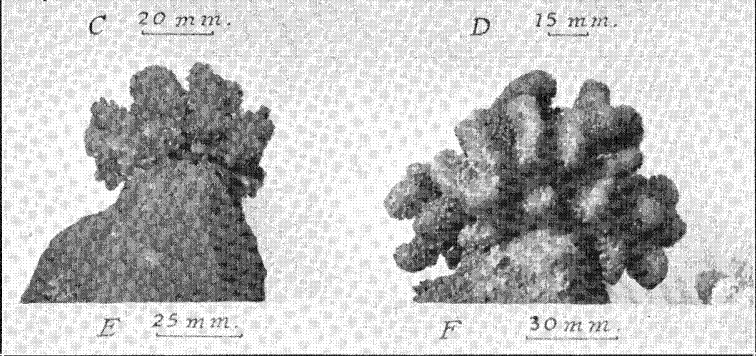

E $25 \mathrm{~mm}$.

A, A BROWN ALGA, PADINA SP, IN 6 MONTHS COMPLETELY SMOTHLRLD THE CORALS PLANTED IN FHIS CEMENT BLOCK; $B_{x}$ A COLONY OF PORTTES LOBATA FORMA INFUNDIBULUM THAT SHOWED A BASAL, EXPANSION OF 4800 MM. IN A YEAR; C, A FRAGMENTED COLONY OF PORITES SP. INFESTED BY BORING ALGAE. THE CLOUDED ZONES IN THF MIDDLE AND UNDER THE SURFACE INDICATE THE PRESENCE OF THF GREFN, FILA. MENTOUS PLANTS; $D$, YOUNG OF FUNGIA SCUTARIA VAR, DENTIGERA BUDDING FROM AN OLD SPECIMEN; E, A COLONY OF POCILLOPORA MEANDRINA VAR. NOBTLIS MAY 15, 1925; F, THE SAME COLONY JANUARY 17, 1927, A GAIN IN HEIGHT OF 36.7 MM. WAS SHOWN IN 613 D.YYS. 
. 



$$
\text { . }
$$





\section{IIPD.}

THE UNMEESITY OF MUCHIGAN GRADUATE LIBRARY

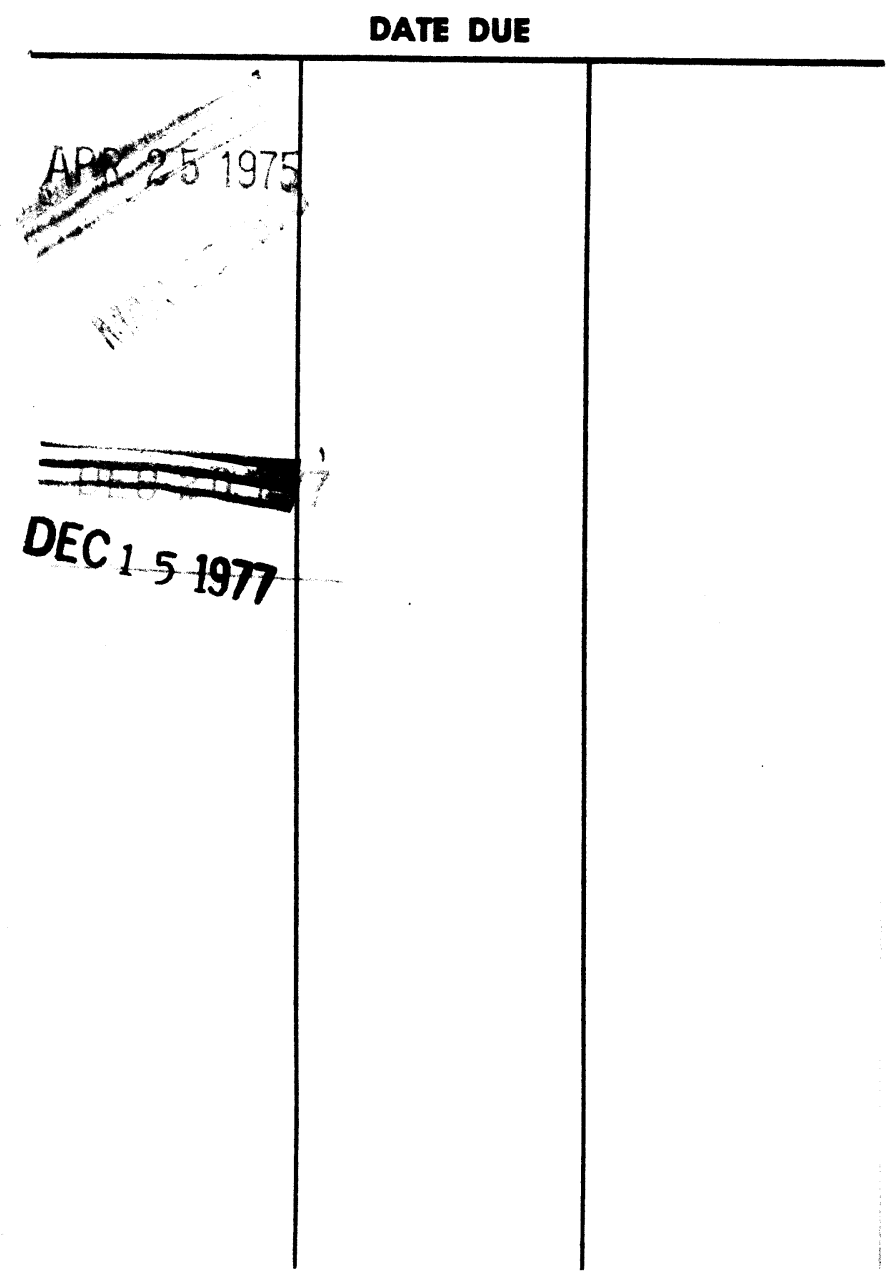


BOUND

AUG2 81944

UNIV. OF MICH. MiERARY

Filmed by Preservation

1996

\section{DO NOT REMOVE \\ OR \\ MUTILATE CARD}


